Volume 8, Issue 1 (Winter 2016)

\title{
Sewing the Body of Christ: Eucharist Wafer Souvenirs Stitched into Fifteenth-Century Manuscripts, Primarily in the Netherlands
}

Kathryn M. Rudy

kmr7@st-andrews.ac.uk

Recommended Citation:

Kathryn M. Rudy, "Sewing the Body of Christ: Eucharist Wafer Souvenirs Stitched into Fifteenth-Century Manuscripts, primarily in the Netherlands," JHNA 8:1 (Winter 2016), DOI: 10.5092/jhna.2016.8.1.1

Available at https://jhna.org/articles/sewing-body-of-christ-eucharist-wafer-souvenirs-stitched-into-fifteenth-century-manuscripts-primarily-netherlands/

Published by Historians of Netherlandish Art: https://hnanews.org/

Republication Guidelines: https://jhna.org/republication-guidelines/

Notes: This PDF is provided for reference purposes only and may not contain all the functionality or features of the original, online publication. This PDF provides paragraph numbers as well as page numbers for citation purposes.

ISSN: $1949-9833$ 


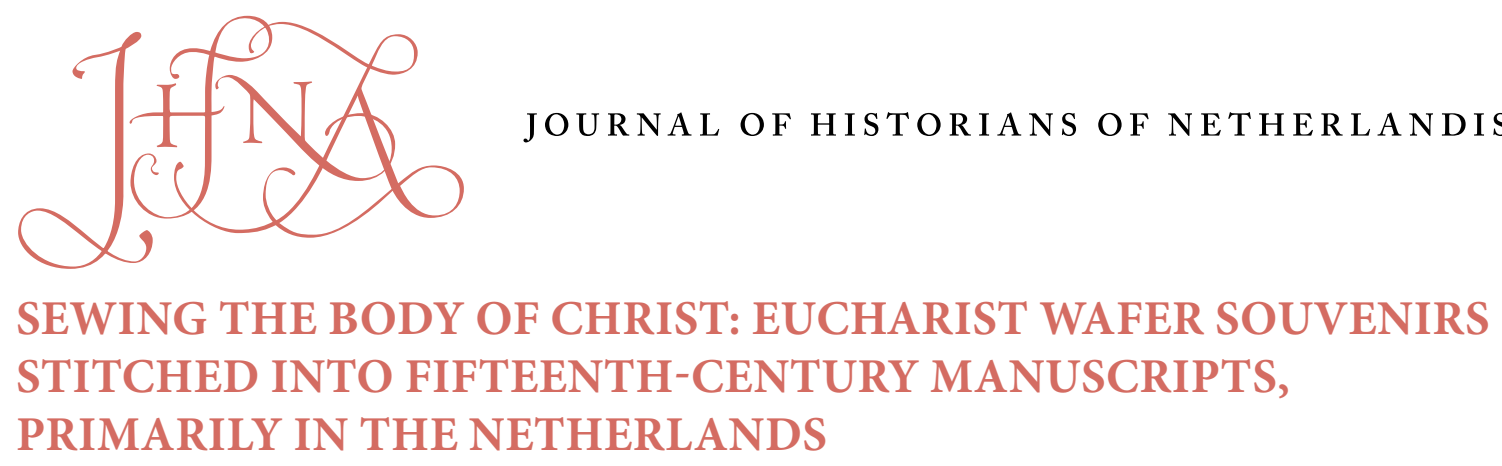

Kathryn M. Rudy

Books of hours in the fifteenth century occupied several social and devotional roles. People used them to store small objects, including metal badges. Although the cultural practice of sewing in badges was widespread in the late Middle Ages, nearly all of the badges have been removed (by later collectors). This article examines the practice by considering needle holes and offsets in the soft parchment, which indicate the shape of the badges and where they were attached. Noting that the vast majority of metal offsets in books of hours are round, the author posits that these were not impressed by pilgrims' badges, as is often repeated in the scholarly literature, but rather by tokens that commemorate having taken the Eucharist. These round badges were the same size and shape and bore the same imagery as host wafers. Owners stitched such badges into their books' margins at locations relevant to Eucharistic piety. When they were sewn into books, Eucharist badges reconfigured the book as a shrine that recorded a votary's pursuit of Communion. DOI: 10.5092/jhna.2016.8.1.1

Receiving the Eucharist created a paradox for medieval believers, who longed for a tangible trace of the body of Christ. The Corpus Christi could, in one sense, be continually renewed through transubstantiation, but once it was created out of a piece of bread and believers had taken the host internally, the visible, tangible trace was gone. In the act of completing the Eucharistic devotion, the object of intense love and scrutiny was quite literally consumed. Materially, at least, the praying subject destroyed the object of devotion precisely by properly venerating it.

2 This paradox should be seen against the backdrop of intense late medieval Eucharistic piety: fourteenth- and fifteenth-century votaries engaged in devotion to the host, which found several outlets, including spiritual and ocular Communion, as well as new offices for the feast of the Corpus Christi, and new prayers to be said before, during, and after taking the host, which became de rigueur for fifteenth-century prayer books. ${ }^{1}$ Despite, or even because the Eucharist had to be consumed and therefore vanished, a material culture developed within books to create a kind of permanence. This article presents two fundamental reconsiderations of the relationship between the Eucharist and the medieval book in the Netherlands. First, that souvenirs of the taking of Communion were not only widely created, but they were also widely collected in manuscripts, where they have been misidentified as pilgrims' badges. Second, that such souvenirs were often sewn into manuscripts to correspond with the times at which Communion was taken. Understanding the hundreds of surviving round tokens as Eucharist badges-which correspond to offsets in the prayer books to which they were once affixed-also has implications for how one 
understands the devotional purpose of the texts. Some prayers, rather than being used every day, were organized around the taking of Communion; Eucharist badges mark that event in the life of the user. The body of Christ, the body of the viewer, and the body of the book are organized into a single arc, such that the book itself becomes a shrine, marking its owner's direct contact with the wafer. $^{2}$

In the fifteenth century small round badges bearing Christological symbols were produced in large numbers. These badges, of which more than six hundred survive, have been categorized as pilgrims' badges, but as I argue, that is a miscategorization that has obscured their original function. They memorialized the Eucharist rather than a pilgrimage; they should therefore not be called pilgrims' badges at all, but rather Eucharist badges. ${ }^{3}$ These objects, made of lead-tin, replicate the size, shape, and iconography of Eucharist wafers but are made of a noningestible material. (I treat similar Eucharist badges made of parchment or paper elsewhere. ${ }^{4}$ These had a different method of production but a similar function to the metallic badges here under consideration.) Eucharist badges therefore have in common with pilgrims' badges the same size and material, and they reveal a similar desire to take home the holy, but they served a function distinct from that of pilgrimage badges. When they were sewn into books, Eucharist badges reconfigured the book itself as a shrine, which recorded a votary's pursuit of Communion.

The books took on a particular topography that reflected the role of Communion; where and how they are sewn into their prayer books can tell us what shape-literally-that role took. Although there are many sources that might help us understand the role that the Eucharist played in lay piety of the fifteenth century (including sermons and miracle stories), here I concentrate on visual, textual, and forensic evidence from manuscript prayer books of Northern Europe. There were different ways to make the body of Christ tangible and immediate: by performing Passion plays, by taking pilgrimages to Jerusalem, by processing the host, by participating in the transubstantiation, by commissioning and using images of Jesus, especially of Christ crucified. I argue here that another way late medieval believers made the body of Christ tangible-and, importantly, permanent - was by collecting and possessing souvenirs of having taken the Eucharist. This amounts to a physicalization via a double derivation - the Eucharist is a proxy of the body and blood, and Eucharist badges are a proxy of the Eucharist. Whereas the Eucharistic bread was edible, one of the functions of the Eucharist badge was to be made of a nondecaying material that would embody permanence. Indestructibility is one of the key features of an object promoted for its memory function. Eucharist badges were part of a very broad process of approximating Christ's body via proxies. Believers used a needle and thread both to repeatedly pierce the ersatz body of Christ (and thereby participate in the Passion) and also to affix the body of Christ into their books and, ultimately, into their memories.

\section{Pilgrims' Badges vs. Eucharist Badges}

5 In the 1860s Arthur Forgeais brought to light the existence of pilgrims' badges, small lead-tin images produced in molds and handed out at pilgrimage sites around Europe. Forgeais published five volumes with engravings made after lead-tin badges dredged from the Seine, thereby setting the stage for the amateur study of badges. ${ }^{5}$ This interest might have instigated the removal of badges from manuscripts, so that amateurs who delighted in small, affordable collectibles could possess them. Many badges, found with metal detectors near wells and streams or culled from 
medieval manuscripts, are still in private collections, although many are now in drawers at historical museums, libraries, and art museums. Sustained academic study began in the 1960s, 70 s, and 80s, when Kurt Köster published a series of articles in which he connected badges with late medieval destinations for pilgrimage, as they often depict saints with their attributes in visually abbreviated forms or represent the shrine where the saint's relics were on display. ${ }^{6} \mathrm{He}$ also identified a number of late medieval manuscripts with badges depicted in their margins. His work initiated further studies to identify and catalogue the surviving badges. A searchable online database called Kunera, directed by A. M. (Jos) Koldeweij at Radboud University in Nijmegen and carefully filled in primarily by Willy Piron and Hanneke van Asperen (http://www.kunera.nl/), represents the culmination of efforts to catalogue them. As of June 2015 this database contained records for 18,971 items, including 14,628 physical badges and 1,122 ampules for holding liquid, such as oil or water from a shrine (fig. 1). Early scholarship therefore conceptualized these objects as pilgrimage badges, a nomenclature that may have stifled other interpretations.

Breakdown by type of the 18,971 items in the Kunera database

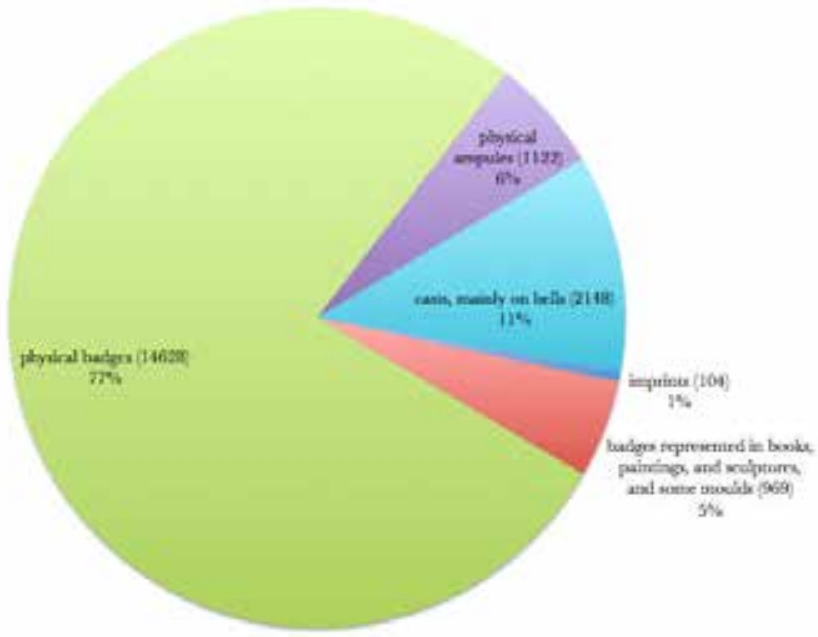

Fig. 1 Breakdown by type of the 18,971 items in the Kunera database.

Badges have appeared in recent exhibitions about pilgrimage, for which catalogue authors portray the badges in terms of completed and remembered pilgrimages. ${ }^{7}$ Other recent commentators, chiefly Isabel von Bredow-Klaus and Megan Foster-Campbell, have emphasized the role of the badges in manuscripts as tools for "spiritual pilgrimage." ${ }^{8}$ Books housed some pilgrimage badges, which served as a reminder of a fulfilled spiritual journey, and provided a structure for contemplative piety. I argue that books also housed tokens of having taken the Eucharist. Clearly pilgrims' badges and Eucharist badges share more than just their material; in discussing the latter, I am also describing material signs of memory, but in this case, not collected in the context of visiting a shrine but of partaking of the body of Christ.

Köster also identified illusionistically painted pilgrims' badges in the margins of certain so-called Ghent-Bruges manuscripts. ${ }^{9}$ Painters of these manuscripts, along with certain illuminators from the Northern Netherlands, often depicted items with a high degree of illusionism, so that the badges they painted into the margins are identifiable. For example, a book of hours illuminated by the Master of Catherine of Cleves contains an image of a badge from a shrine of Saint James, 
showing the saint under an elaborate gothic armature (Baltimore, Walters Art Museum, Ms W 782 , fol. 113r; fig. 2). The badge is depicted affixed to a shell, also associated with the pilgrimage to Santiago de Compostela, which becomes part of the border design alongside other shells. ${ }^{10}$ Köster and others proposed that illuminators, by painting badges in the margins of manuscripts such as this, were imitating a practice of inserting physical badges into a manuscript. Their proposal is corroborated by several surviving books of hours that still contain physical badges such as these, sewn to the parchment. ${ }^{11}$ Painters were therefore reflecting on a cultural practice, or even enhancing it. The Master of Catherine of Cleves went beyond what was possible by depicting a deeply three-dimensional object (a shell of Saint James) that would have been impossible to press within a book. Painters, in other words, could recreate idealized versions of ritual practice. It is unclear whether owners of manuscripts with such painted decoration had actually undergone pilgrimages, or whether these were just vestigial decorations that imitated an earlier practice without the actual pilgrimage. As I show below, painters also illusionistically depicted what I am calling Eucharist badges in manuscript margins. When they did this, they were reflecting on the widespread practice of sewing Eucharist badges into manuscripts.

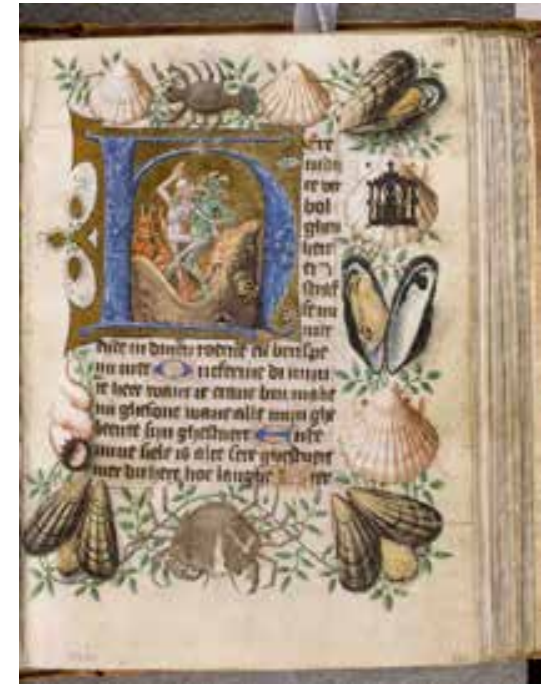

Fig. 2 Folio from a book of hours with illumination attributed to the Master of Catherine of Cleves. Baltimore, Walters Art Museum, Ms W 782, fol. 113r (artwork in the public domain)

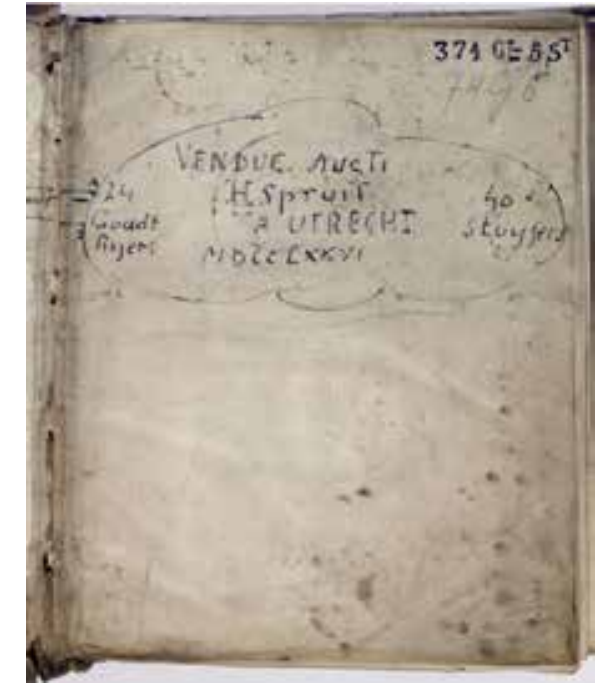

Fig. 3 Flyleaf with offsets of round metallic objects that have since been removed. The Hague, Koninklijke Bibliotheek, Ms $74 \mathrm{G} 5$, fol. Ir. (artwork in the public domain)

Although such painted representations suggest a common destination for badges-and a few medieval manuscripts with badges affixed to them do exist-most manuscript prayer books have had their badges removed. Because parchment is soft and organic, it holds the offset of the low relief badges long after they are gone. Most often these offsets only trace the badge's outline, as well as a few points from the badge's highest protrusions, but such constellations of dark marks do not provide enough information to securely identify the object that made the impression. Rather, such a trace only gives an indication of the size and shape of the hard object that imprinted it. These offsets also present another piece of forensic evidence. They are usually ringed by needle holes, which testify to the manner of affixing: by sewing. ${ }^{12}$ (Very occasionally they were glued in instead.) The large number of such offsets and needle holes that appear in books of hours and prayer books indicates the broad extent of the practice of stitching metallic badges into books. 
Hanneke van Asperen has compiled the fullest catalogue to date of such material in her dissertation, whose title one could translate as "Pilgrims' Badges on Parchment: Souvenirs of Pilgrimage-Original Objects as well as Their Painted Representations-in Religious Books (ca. 1450-ca. 1530)," in which she identifies many examples of late medieval manuscripts with imprints (or offsets) of badges or paintings of such badges in the margins. ${ }^{13}$ A few of the offsets she studied were clear enough to hypothesize the iconography of the now-missing badge, but the bulk of these were not identifiable, just revealing an indentation and needle holes in a particular pattern that would have circumscribed the hard object. Such offsets indicate that a badge was once present but not which badge it was. However, the offsets do indicate the shapes of the now-missing badges. To choose one example among many, the first flyleaf of a book of hours now in The Hague has unidentifiable offsets (The Hague, Koninklijke Bibliotheek, Ms 74 G 5, fol. Ir; fig. 3). It is clear from the pattern of darkening that the badges were round and were densely packed near the top of the folio and that the owner began to make two columns of them in the lower half of the folio, as if he or she were collecting them and anticipating from the outset that the badges would eventually fill the page. The badges were not, in other words, affixed haphazardly but with an end goal in mind. That is the urge of the collector: to fill the cabinet, the shelf, the page. In this case, the owner has done so with organized packing to maximize the badges per page, even though the badges are of various diameters and resist neat rows. But he or she reached the ultimate deadline-death-before meeting the collection goal. Such offsets on parchment are our primary means of knowing how medieval people stored their badges, or at least one way they did so, so that they would accompany their owners through life and beyond.

10 Browsing through the Kunera database, one can see that many badges can be associated with specific saintly shrines and that they take all manner of forms (fig. 4). Many of them show a saintly figure under a gothic arch, which connotes an architectural shrine. Some show the saint with his/ her attribute, such as Christopher carrying the Christ Child. Some show just the saint's emblem, such as the tau cross associated with Saint Anthony or an arrow for Saint Ursula. Others reduce a cult object or relic to a highly abbreviated form. For example, the badge from Wilsnack shows the three miracle-working hosts proffered at that site and has a trilobed form. ${ }^{14}$ Other badges cited in the database are variously described as square, rectangular, oval or rhomboid, or round. Of the round ones, only a few can be associated with a particular pilgrim's shrine but most cannot. It is to these shrine-less badges that I direct attention.

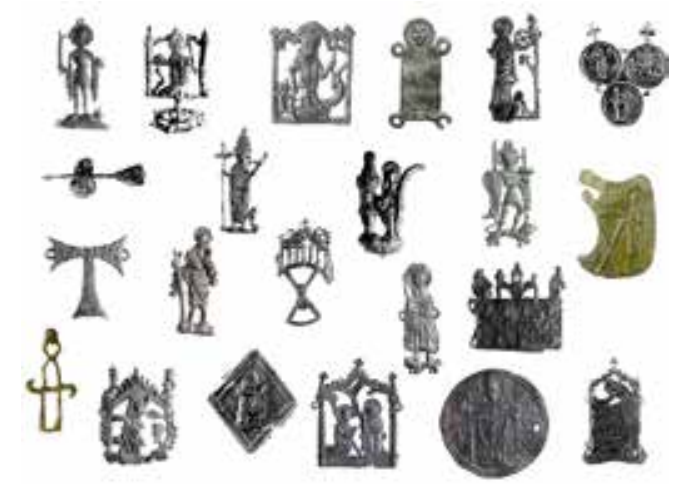

Fig. 4 Selection of pilgrims' badges from known shrines, culled from the Kunera database

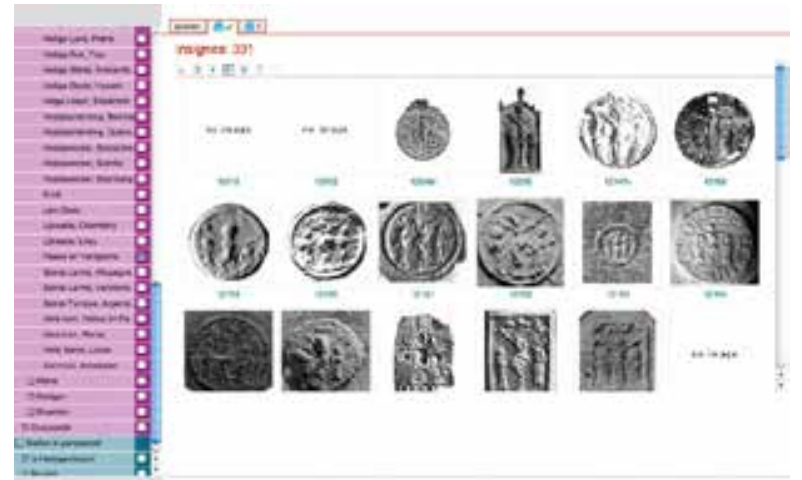

Fig. 5 Screen shot of the Kunera database showing a selection of the 331 badges with Passion and Resurrection subjects, which are not connected to a particular pilgrimage shrine. 


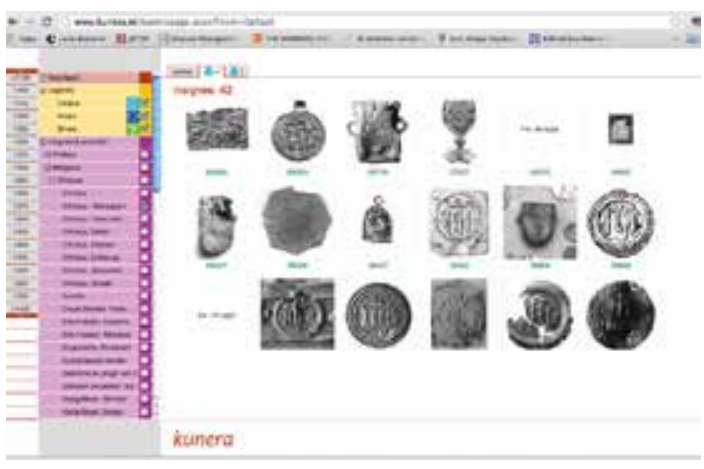

Fig. 6 Screen shot of the Kunera database showing a selection of the badges with the IHS monogram.

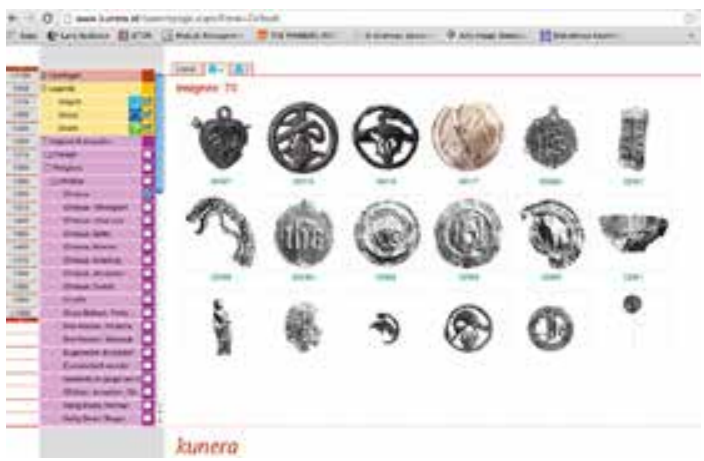

Fig. 8 Screen shot of the Kunera database showing a selection of the badges showing a pelican piercing its breast.

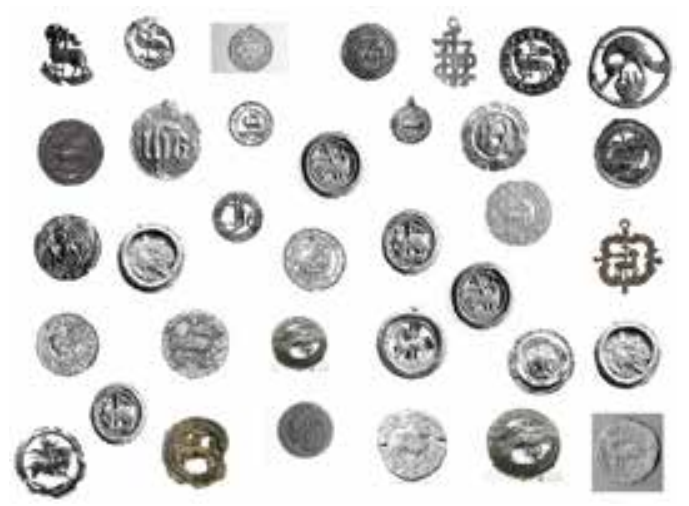

Fig. 10 Christological badges with the Lamb of God, what I am terming here Eucharist badges, culled from the Kunera database

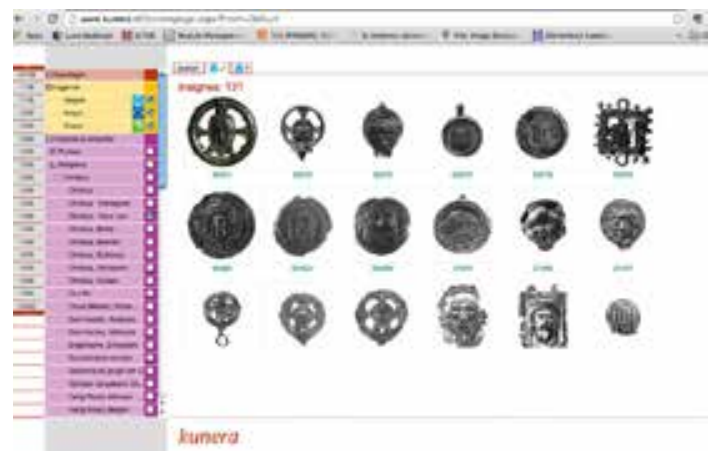

Fig. 7 Screen shot of the Kunera database showing a selection of the badges with the face of Christ.

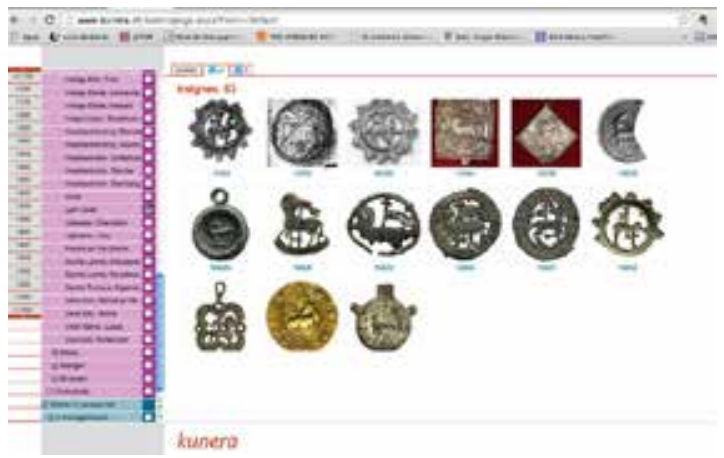

Fig. 9 Screen shot of the Kunera database showing a selection of the badges with the Lamb of God.

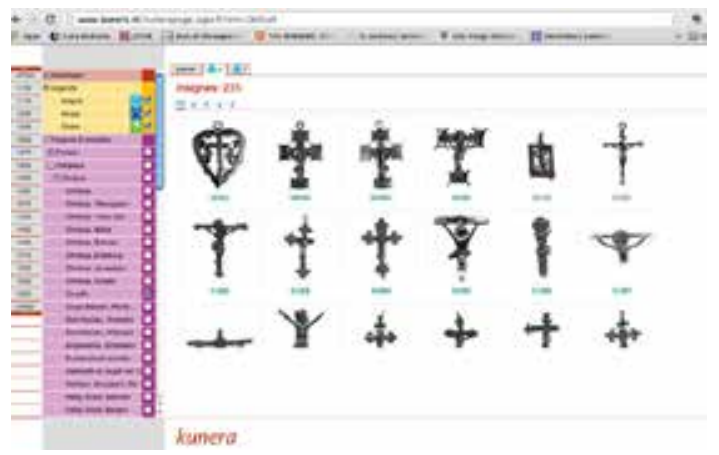

Fig. 11 Screen shot of the Kunera database showing a selection of cruciform objects.

11 In the Kunera database, badges are organized according to the relics and pilgrimage destinations they portray, such as the "Holy Lance of Nuremberg." However, several subcategories under "Christus" have no place associated with them. These place-less badges include 331 with Passion subjects such as the Crucifixion and Resurrection (fig. 5); 42 with the IHS monogram (fig. 6) $;^{15} 131$ with the face of Christ, which are distinct from those which can be associated with the Vera Icon pilgrimage in Rome (fig. 7); 70 showing a pelican piercing its own breast to feed its young with its own blood, understood as a Eucharistic metaphor for Christ's sacrifice (fig. 8); and 
83 badges depicting the Lamb of God (fig. 9). These add up to 657 examples of Christological badges that are independent from pilgrimage shrines. Most of these generic, place-less Christological badges are round (fig. 10). These Christological badges survive in dozens of varieties, each survivor pointing to hundreds or thousands of lost examples. It is possible that churches throughout the Netherlands and Germany distributed such badges on a wide scale.

12 Also unconnected to identifiable shrines are 235 badges categorized as a "Crucifix" (fig. 11). Because many of these have a hanger at the top, they may have functioned as cheap religious jewelry rather than as tokens of either a pilgrimage or receiving Communion. Some percentage of the round badges also have a hanger, as if their makers were anticipating that recipients would hang the objects around their necks or brandish them on the body in some other fashion after receiving them as tokens of having taken the Eucharist (fig. 12). In this way the wearer would be able to quietly broadcast his or her recent Communion.

13 There is also a class of badges from shrines associated with Eucharistic miracles, which are relevant to understanding how the host was represented in base metal. These include badges from Andechs in Bavaria, which housed three miraculous hosts, one of which was said to have the IHS monogram written in blood (fig. 13). At the center of the badge the smith has represented these specific hosts, which appear very similar to the round disks with the Lamb of God, Crucifixion, and IHS monogram mentioned above. Noteworthy is the length to which the smith went to depict specificity of place, by adding the coat of arms of the convent in Andechs at the bottom of the frame. When a smith omitted such a locational reference, he was creating Eucharist badges that any church could distribute.

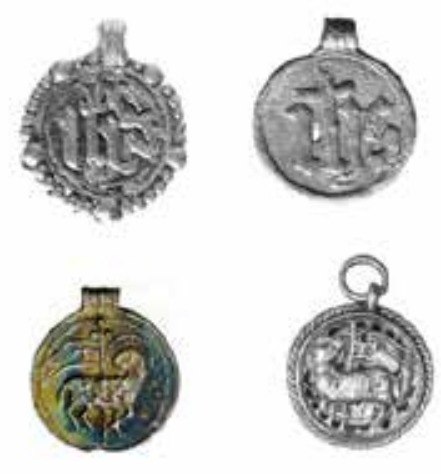

Fig. 12 Four round Christological badges with hangers from the Kunera database.

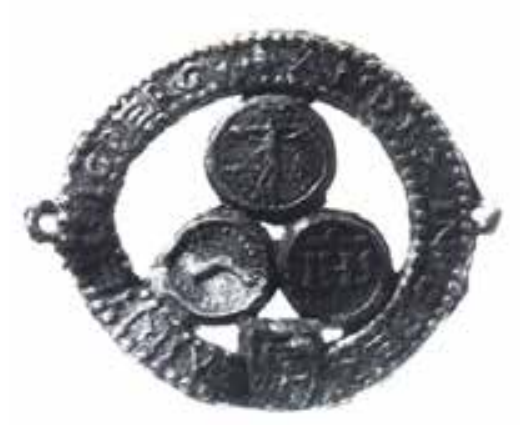

Fig. 13 Badge of the three miraculous hosts of Andechs (Kunera no. 06534)

14 The Andechs badges are close in form to a group that were distributed at Wilsnack, which likewise portray three round hosts bearing Passion images that closely resemble what I am calling Eucharist badges (fig. 14). That three of them appear together in a trilobed form, rather than as individual round forms, distinguishes them as Wilsnack's particular miracle-working hosts. Some 150 badges from Wilsnack survive, most of them with this trilobed form. In some badges, the iconography of the individual hosts differs, but they usually communicate Passion themes (fig. 15). A more complicated iconography appears on badges from Blomberg (Germany), whose shrine featured hosts that had supposedly been desecrated when a woman threw a batch of them 


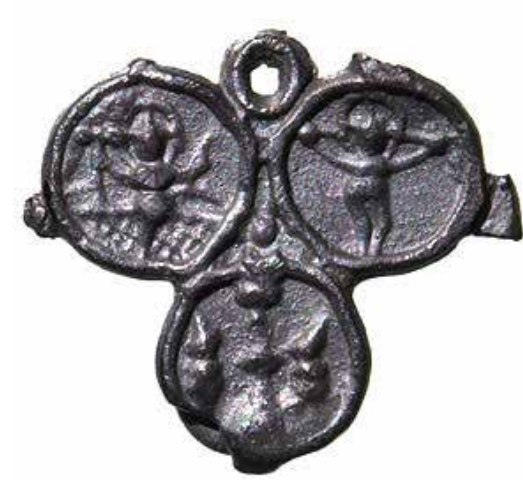

Fig. 14 Badge of the three miraculous hosts of Wilsnack (Kunera no. 00135)

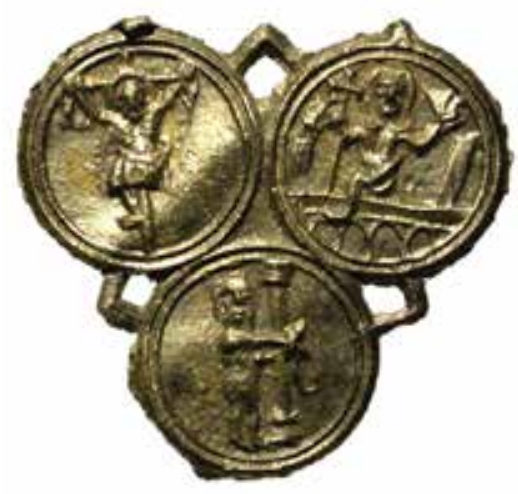

Fig. 15 Badge of the three miraculous hosts of Wilsnack, showing three hosts bearing Passion imagery (the Crucifixion, Resurrection, and Flagellation) (Kunera no. 13628)

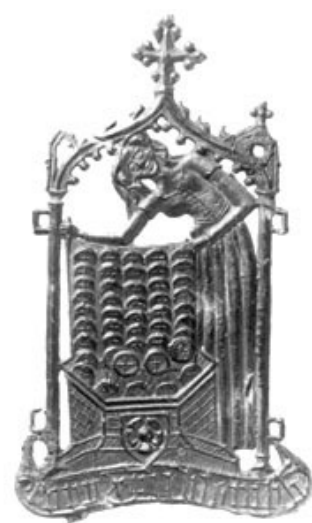

Fig. 16 Badge of the host desecration at Blomberg, showing a woman throwing forty-five hosts into a well (Kunera no. 04674)

into a well (fig. 16). Here the hosts are represented as round disks bearing a simple cross. Like the badge from Andechs, this one specifies the pilgrimage site which it depicts, in the form of an inscription: "CORP[US] XPI I BLOMBH" (Corpus Christi in Blomberg). Such pilgrims' badges confirm that the simpler round badges I cite above are meant to represent hosts.

15 William J. Courtenay has recognized yet another class of round metal objects from the late Middle Ages, adding another set of functions to the large and varied corpus of souvenirs. ${ }^{16}$ These tokens were made of lead, or other soft, cheap metals, and bore the insignia of the institutions that commissioned them. Many of them have been found in rivers-the Seine and the Scheldte-near the most important charitable institutions of Paris and Antwerp, respectively. He writes, "Ranked according to the number of tokens that have survived, the issuing agencies were primarily ecclesiastical, followed by guilds and confraternities, and, finally, municipal governments. Functions that have been ascertained for these objects range from a means of paying workers, tax or merchandise receipts, membership passes, means of internal accounting, means of recording the performance of duties, to a means of facilitating the distribution of charity." ${ }^{17}$

16 Courtenay's research indicates that since molded lead-tin "badges" can be any shape and have many different forms one should not assume, in such a varied visual culture, that all of the objects made of this material were for a single purpose. Moreover, 29 percent of surviving badges present profane themes (fig. 17), such as penis trees and ambling vulvas, and it is clear that such badges may present the world upside down, or mock pilgrimage badges, but they do not serve as souvenirs of a sacred journey. Likewise, as Carina Brumme has recently shown, miniature crowns made of molded lead-tin, of which several dozen survive from the late Middle Ages, fell into two categories. Those with a chain of lilies were pilgrims' souvenirs from Boulogne-sur-Mer, which possessed a cult image of the Virgin and Child; those with images of labors of the month, or with references to Epiphany, were used in drunken folk festivals that took place on the sixth of January when the Bean King was crowned. ${ }^{18}$ It is against this backdrop of a wide variety of badges, with a plurality of uses, that I posit that many supposed pilgrims' badges with Christocentric iconography are actually Eucharistic souvenirs. Some badges are clearly associated with saintly shrines, thanks to their microarchitectural frames, and while the Christologically generic ones can come 
in multiple shapes, the vast majority of them are round. These round badges that cannot be connected to a pilgrimage shrine have been misclassified as pilgrims' badges. They do not belong to a history of pilgrimage so much as to a history of the Eucharist.

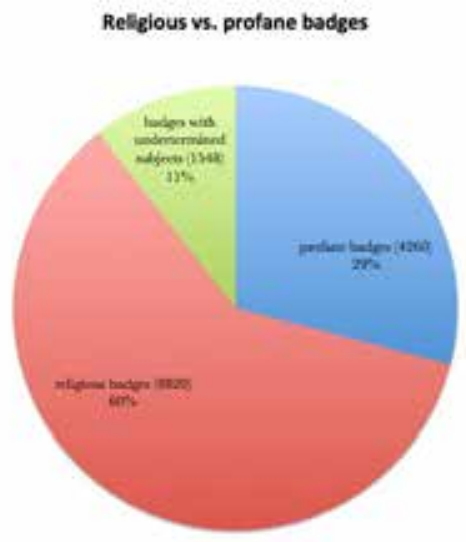

Fig. 17 Chart comparing religious and profane badges in the Kunera database.

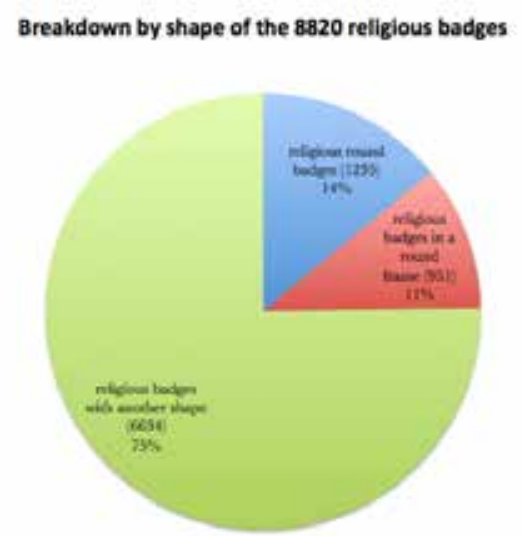

Fig. 18 Chart breaking down the religious badges by shape. of surviving religious badges 14 percent are disklike (bracteate) in form, while 11 percent incorporate open latticework surrounded by a round frame.

17 Furthermore, although round badges constitute only 25 percent of surviving religious badges (fig. 18), round offsets form a disproportionately large number of the badges sewn into manuscripts, as the figures in this article attest. To make the case that these commemorated not a pilgrimage but rather the consumption of the Eucharist, I will look at their iconography more carefully and also consider, by forensic means, where in the manuscripts the round offsets are found. I am concerned not only with what the round badges represent but with what associations their original audiences ascribed to them. To do this, I consider the tangible trace the badges left in books, then categorize and interpret the results of those autopsies.

\section{Eucharist Wafers: Bread and Metal}

18 The host wafer turned bread into a substrate for an image. The Eucharist wafer mirrored the badges not just in shape but in being the bearer of an image, as though the wafer anticipated its imitation. Hosts were always round, and they provided a surface for a variety of Christological images and symbols. They were baked in forms not unlike waffle irons, in which two metal surfaces attached to long handles pressed balls of dough (or batter) between the two surfaces. ${ }^{19}$ The closed iron was then set into a fire, so that the resulting disks of bread had a relief form baked into their very structure. As Miri Rubin points out, as of the twelfth century Eucharist wafers were baked with an image of the Crucifixion or the Lamb of God. ${ }^{20}$ Several medieval host irons survive that confirm this. One, now in Stockholm, makes six hosts at once and displays a variety of Resurrection motifs, as well as an image of the Lamb of God with the bannered cross staff, which closely resembles the sort routinely depicted in illuminated manuscripts (fig. 19).

19 According to scripture, John the Baptist, pointing to Jesus, uttered, "Behold the Lamb of God that taketh away the sin of the world" (John 1:29). In visual terms, the image of the Lamb of God became a common motif in Christian art of the Middle Ages, often taking the form of the 


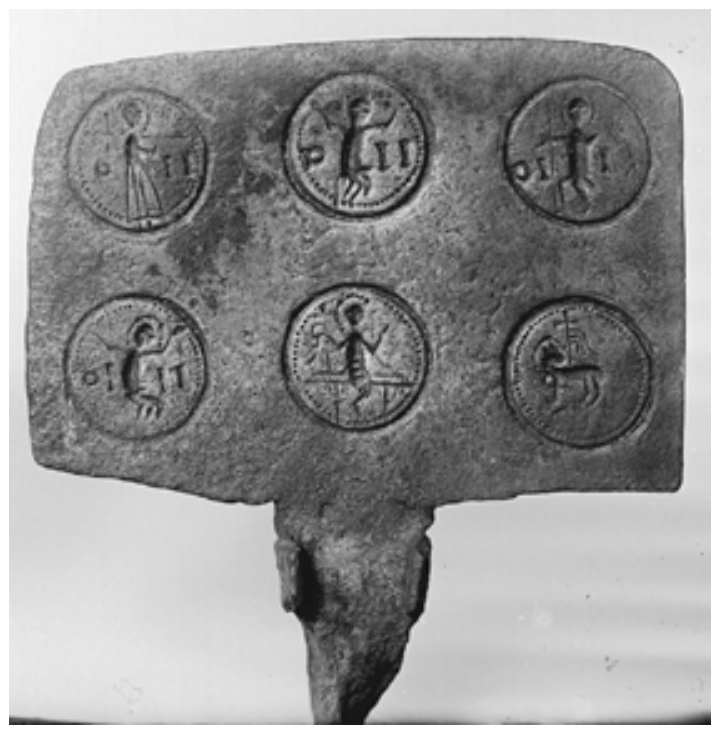

Fig. 19 Eucharist wafer iron, ca. 1390-1410.

Stockholm, Statens Historiska Museum (Museum of

National Antiquities) (artwork in the public domain)

Lamb carrying a bannered cross staff, which referred to the sacrifice of Jesus and his triumph over death. The motif appears, for example, at the center of the Ghent Altarpiece, also known as the Adoration of the Mystic Lamb, painted by Jan van Eyck in 1432. This painting depicts, at one level, all of the saints gathering in Paradise to venerate the Lamb of God on an altar, in other words, the elevated host. The isolated motif of the Lamb of God also appeared on seals, liturgical garments, stained-glass windows, and all other manner of ecclesiastical furnishings. Furthermore, the motif appeared on perishable media, above all, on Eucharist wafers.

20 The Lamb of God host closely resembles, in iconography, size, and form, Eucharist badges formerly sewn into late medieval manuscripts. Round images that repeat this and other Christological images and symbols commemorate the host. That the hosts bore different possible images opens the possibility that believers would seek to ingest all the various varieties or to collect them in metallic replicas. The round form, the small size, and the Eucharistic iconography of host wafers announce their relationship with the metallic badges introduced above.

21 Believers only rarely had access to the real host, although they desperately would have liked to take Communion more often. As Rubin notes, "Consecrated hosts were to be kept in a manner which emphasized their fundamental difference from any other artifact in or outside the church. They were to be consumed only by priests, servers, and on special occasions, like Easter, by the communicating laity, and were occasionally taken out on visitations of the sick, for some healing and blessing functiones sacrae, and for use in the Easter sepulcher." ${ }^{21}$ Taking the host at Easter was an annual event for many laypeople, one introduced by a long drum-roll of Lent and Passion week. I suggest that the communicants would have wanted to commemorate this experience with a metallic or other (semi-) permanent token.

22 Not only did votaries long to ingest the host, but they wanted to see it as well. They strained to see it at the elevation, for doing so yielded untold spiritual rewards. "In a sermon for a Sunday after Epiphany 1375 Bishop Brinton of Exeter taught that after seeing God's body no need for food would be felt, oaths would be forgiven, eye-sight would not fade, sudden death would not 
strike one, nor would one age, and one would be protected at every step by angels." 22 People tried to steal sanctified hosts, because they promised untold thaumaturgic benefits. One believer, for example, was caught burying a sanctified host under a barrel of beer she was brewing, "to insure," she reported, "that her beer was better than her neighbor's." ${ }^{33}$ So powerful was the host, and so multifold the possibilities of performing misdeeds with it, that it was normally placed under lock and key and only consumed by the priestly celebrant. Perhaps all of the efforts to keep the host away from the laity only stoked their desire for it, and perhaps metallic replicas were seen as a safe alternative, which could not be desecrated, improperly venerated, or left to mold. People were free to bury them under beer vats if they so desired, and to touch and gaze at them at will.

\section{Where They Appear In Manuscripts}

23 When prayers associated with the ritual of taking Communion were included in prayer books they created a locus for materializing the object of veneration, which I maintain often consisted of a round badge as an ersatz host. For the remainder of this essay, I consider the physical locations of round metallic badges, ${ }^{24}$ as evidenced by their offsets, and ask: where, physically, did owners affix them into their books? By far the most offsets of this sort occur at two places in a book of hours: at the Hours of the Cross and at the Penitential Psalms and Litany of the Saints. Although art historians studying books of hours have generally assumed that votaries read all of the Hours (i.e., the Hours of the Virgin, of the Cross, of the Holy Spirit, of Eternal Wisdom, and so forth) each day, I strongly suspect that such a view of medieval devotional habits is incorrect. ${ }^{25}$ It is likely that the votary would have only read the Hours of the Cross during liturgically appropriate times of the year, namely during Passion week leading up to Easter. Likewise, the votary would take up the Hours of the Holy Spirit in the week before Pentecost, the Hours of the Virgin on Mary's many feast days, and the Penitential Psalms during the season of repentance, namely Lent. If this is true, then taking the Eucharist was the culmination either of a weeklong cycle of reading the Hours of the Cross or of a forty-day cycle of reading the Penitential Psalms.

24 Understanding these round forms as Eucharist badges has implications for how one understands the devotional purpose of the texts next to which they are placed. Prayers, rather than being used every day, were organized around the taking of Communion: they reiterated the importance of this event in the user's life. The image on the badge, such as the Lamb of God that takes away sins, is a tangible sign of an intangible act: the exculpation of sin. It made a difficult abstract concept literally graspable. By considering where in books of hours offsets of badges appear one can better understand how medieval votaries understood their Eucharist badges and their books. In the act of affixing them, votaries created a dialogue between the badges and the various texts and images in their books. Seeing where votaries placed their Eucharist badges provides an indication of how they viewed them.

\section{A. Around Sacramental Themes}

Many books of hours made in the fifteenth century have a section of prayers dedicated to the Eucharist. A standard iconography never emerged to preface these prayers. Given my hypothesis laid out above, it is no surprise that many Eucharist badges or their offsets appear in manuscripts at prayers dedicated to the Sacrament. Owners associated their badges with such prayers and filed them accordingly. I have located offsets of round badges in the following manuscripts: 


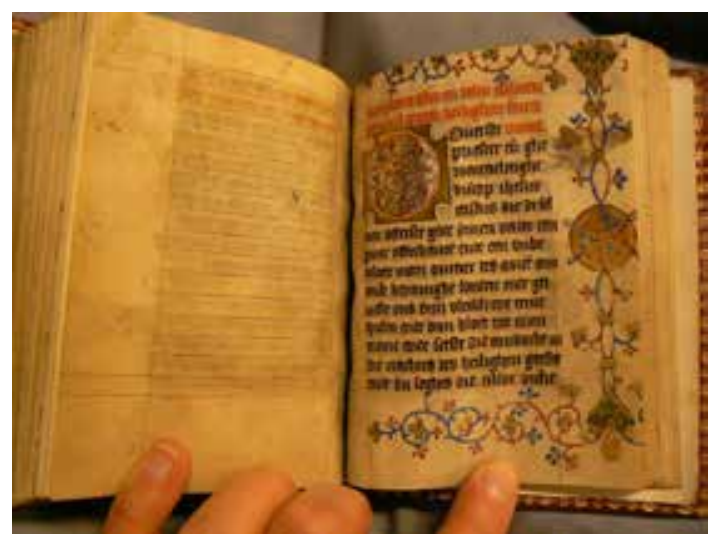

Fig. 20 Incipit of prayers to the Sacrament, with an offset of a round badge on the left-hand folio. The Hague, Koninklijke Bibliotheek, Ms $131 \mathrm{H}$ 10, fols. 202v-203r (artwork in the public domain; photo by the author)

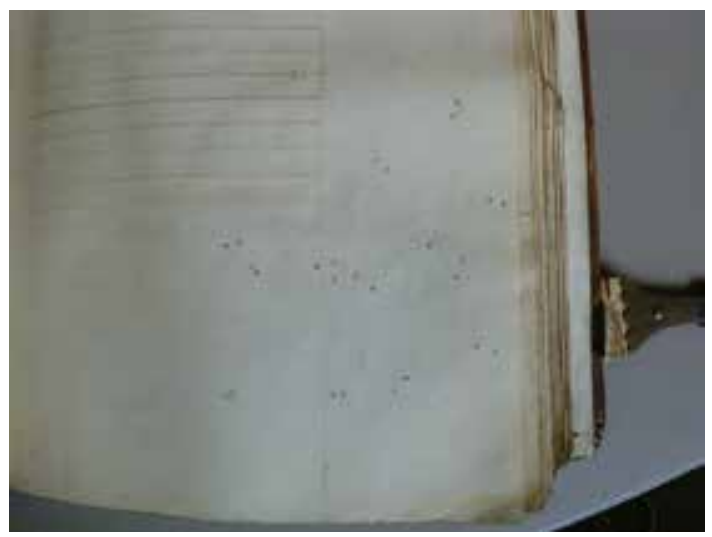

Fig. 22 Lower margin from of a book of hours just before prayers to the Sacrament, Bruges, Stadsbibliotheek, Ms 674, fol. 115r (artwork in the public domain; photo by the author)

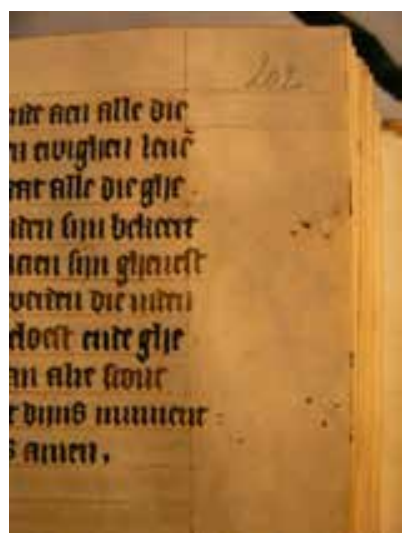

Fig. 21 Detail of fig. 20 (artwork in the public domain; photo by the author)

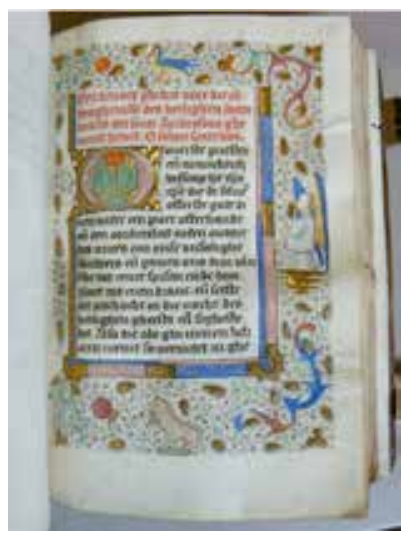

Fig. 23 Opening of a book of hours, with the incipit for prayers to the Sacrament. Bruges, Stadsbibliotheek, Ms 674, fol. 116r (artwork in the public domain; photo by the author)

1. A book of hours made in Delft ca. 1430 contains prayers to the Sacrament, where an owner has affixed a round badge to the blank folio prefacing these prayers (The Hague, Koninklijke Bibliotheek, Ms $131 \mathrm{H}$ 10, fols. 202v-203r; fig. 20). A detail reveals the needle holes (fig. 21).

2. A book of hours, possibly written in Haarlem and with penwork from Haarlem but with painted borders added in Delft, has a series of prayers to the Sacrament (Bruges, Stadsbibliotheek, Ms 674, fol. 116r; fig. 22). Someone has sewn in a number of small objects to the blank facing folio (Bruges, Stadsbibliotheek, Ms 674, fol. 115r; fig. 23). Sewn-in objects have been removed, and now only the needle holes are still visible. As the objects did not emboss the parchment, it is possible that they were made of parchment rather than metal.

3. A book of hours made in the Northern Netherlands in the second quarter of the fifteenth century has a round badge offset (Brussels, Koninklijke Bibliotheek Albert 
I, Ms IV 1000, fol. 158r; fig. 24). This manuscript contains a prayer to the Sacrament, which was not accompanied by a miniature. The manuscript otherwise has full-page miniatures by the Gethsemane Master, who was active in Utrecht ca. 1430-1450.

Miniatures of the Sacrament were not systematically part of the "package" of miniatures that apparently came ready-made for insertion into plain books of hours. But the owner wanted to mark, and personalize, the prayer to the Eucharist and has therefore inserted a round badge to mark its incipit. Its rubric proclaims: "Een goet ghebet vanden heiligen sacrament dat sinte Ambrosius hevet gemaect ende plachte te lesen als hi ter missen ghinc" (A good prayer to the holy Sacrament that Saint Ambrose wrote and used to read when he went to Mass). By reading this prayer, the votary can follow Saint Ambrose to the altar. The owner affixed a round badge, presumably a Eucharist badge, to the bottom margin.

\section{B. At the Hours of the Cross and the Hours of the Passion}

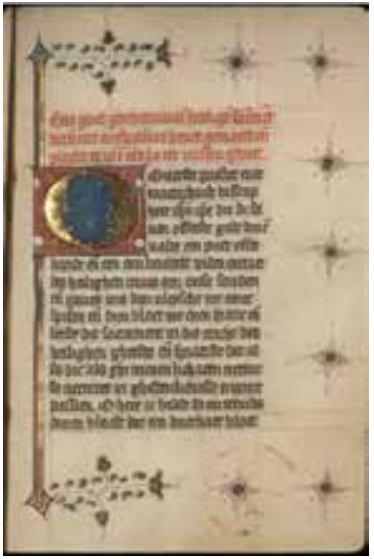

Fig. 24 Incipit of a prayer to the Sacrament, with a round offset. Brussels, Koninklijke Bibliotheek Albert I, Ms IV 1000, fol. 158r (artwork in the public domain)

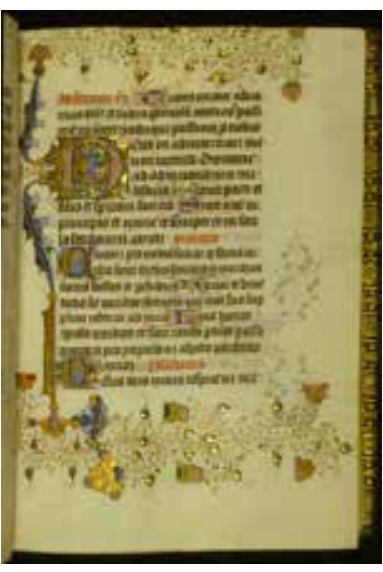

Fig. 27 Text page from the Hours of the Passion. Cambridge, Fitzwilliam Museum, Ms 135, fol. $23 r$ (artwork in the public domain)

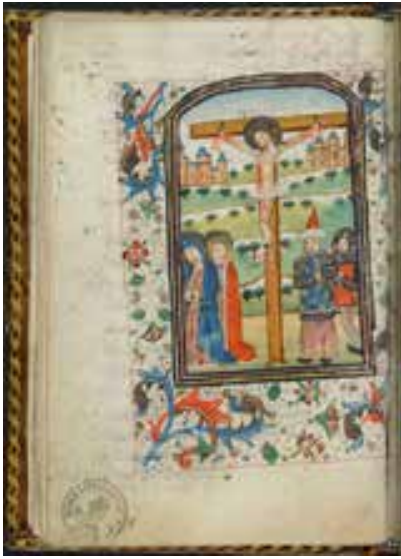

Fig. 25 Crucifixion miniature to preface the Hours of the Cross, with several offsets of round badges in the margin. Brussels, Koninklijke Bibliotheek, Ms 10541, fol. 10v. (artwork in the public domain)

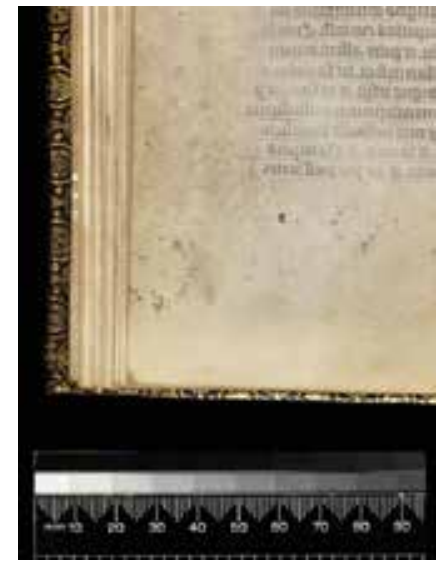

Fig. 26 Detail of last page of the Hours of the Passion. Cambridge, Fitzwilliam Museum, Ms 135 , fol. 32v (artwork in the public domain)

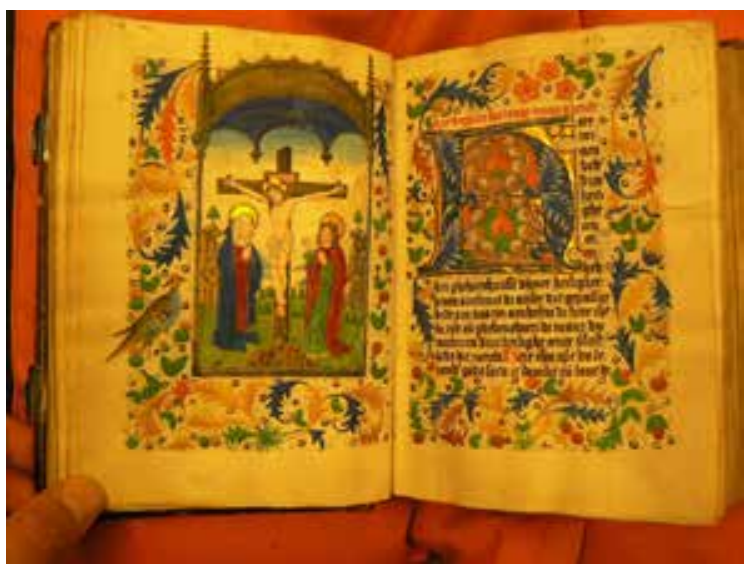

Fig. 28 Full-page Crucifixion, inserted before the Long Hours of the Cross, with round offsets. The Hague, Koninklijke Bibliotheek, Ms BPH 137, fols. $13 \mathrm{v}-14 \mathrm{r}$ (artwork in the public domain; photo by the author) 


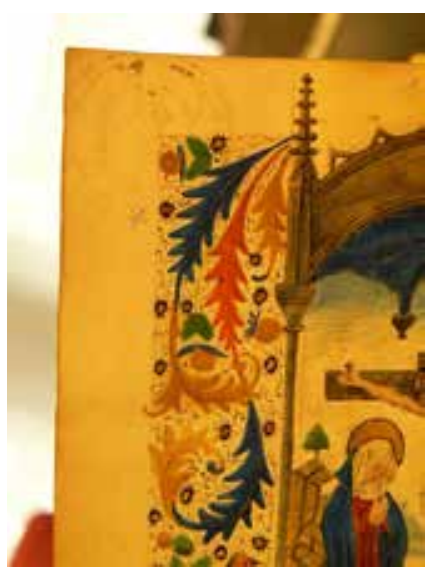

Fig. 29 Detail of the top left corner of the Crucifixion miniature (fig. 28: fol. 13v), photographed with backlighting to reveal needle holes (artwork in the public domain; photo by the author)

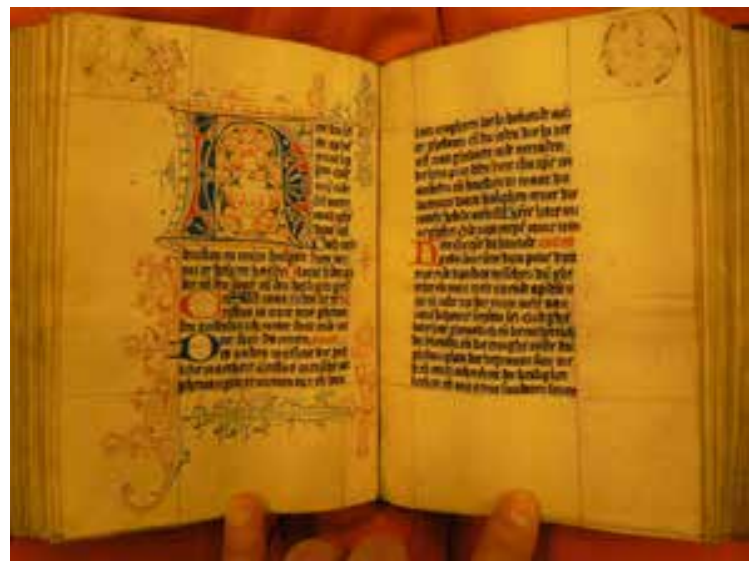

Fig. 31 Incipit of the Short Hours of the Cross, with an offset from a round badge. The Hague, Koninklijke Bibliotheek, Ms BPH 137, fols. $100 v-101 r$ (artwork in the public domain; photo by the author)

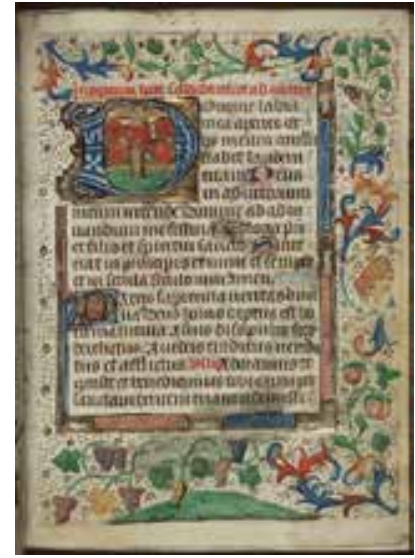

Fig. 33 Incipit of the Hours of the Cross, with round offsets. The Hague, Meermanno Museum, Ms $10 \mathrm{~F}$ 15 , fol. $8 \mathrm{r}$ (artwork in the public domain)

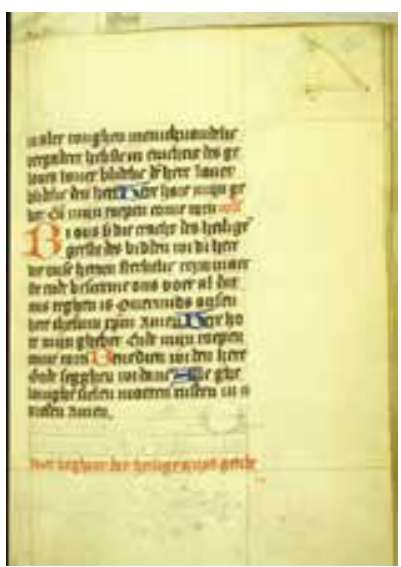

Fig. 30 Thread from sewing-in the round badge on the folio with the rubric announcing the Short Hours of the Cross. The Hague, Koninklijke Bibliotheek, Ms BPH 137, fol. 100r (artwork in the public domain; photo: Byvanck Genootschap)

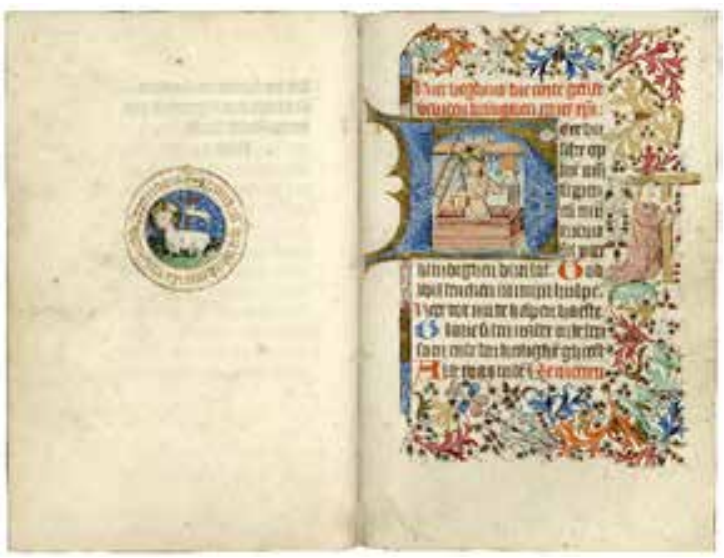

Fig. 32 Lamb of God with inscription (parchment painting in its current manuscript context, trimmed into a roundel) before the Hours of the Cross. Olim Delft, Prinsenhof, fols. 52v-53r (artwork in the public domain)

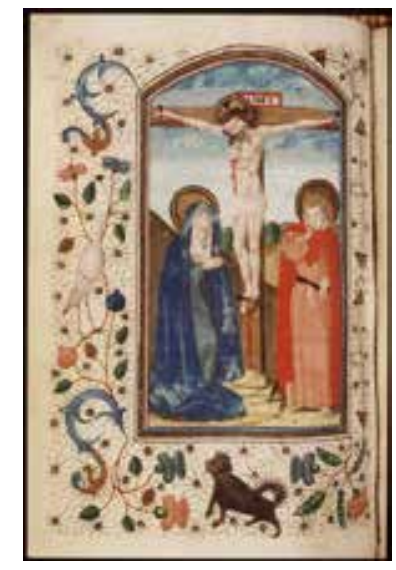

Fig. 34 Crucifixion prefacing the Hours of the Cross, with a round offset. The Hague, Koninklijke Bibliotheek, Ms $135 \mathrm{E}$ 22 , fol. $103 \mathrm{v}$ (artwork in the public domain) 


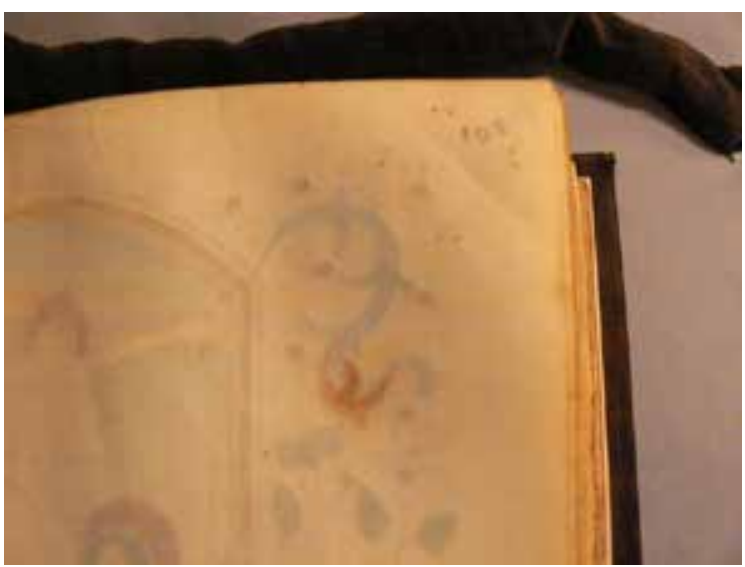

Fig. 35 Detail of needle holes. The Hague, Koninklijke Bibliotheek, Ms $135 \mathrm{E} 22$, fol. $103 \mathrm{r}$ (artwork in the public domain; photo by the author)

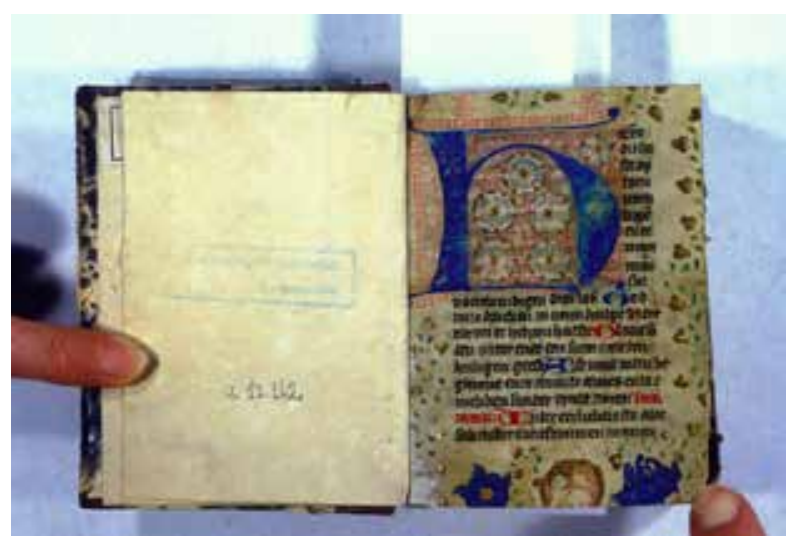

Fig. 37 Incipit of the Short Hours of the Cross, with a Lamb of God roundel painted in the margin. Olim Nijmegen, Jezuitenbibliotheek Berchmanianum (now Leuven, Maurits Sabbebibliotheek), Ms 5000 A 30, fol. 1r (artwork in the public domain; photo: Byvanck Genootschap)

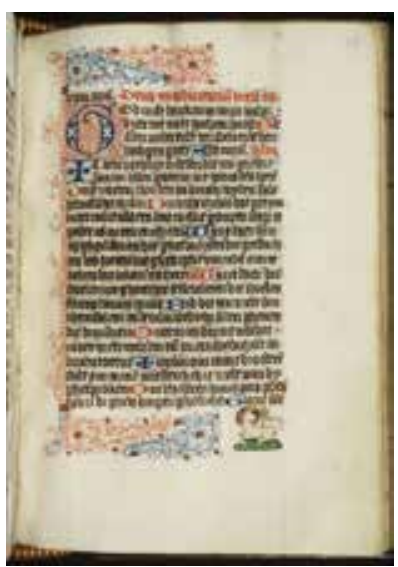

Fig. 36 Folio from the Hours of the Cross, with the Lamb of God painted in the lower margin. The Hague, Koninklijke Bibliotheek, Ms 135 E 22, fol. 117r (artwork in the public domain)

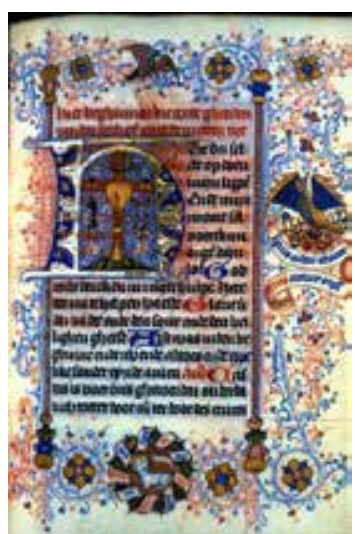

Fig. 38 Incipit of the Short Hours of the Cross, with a Lamb of God roundel painted in the margin. Oxford, Bodleian Library, Douce Ms 248 , fol. 66r (artwork in the public domain)

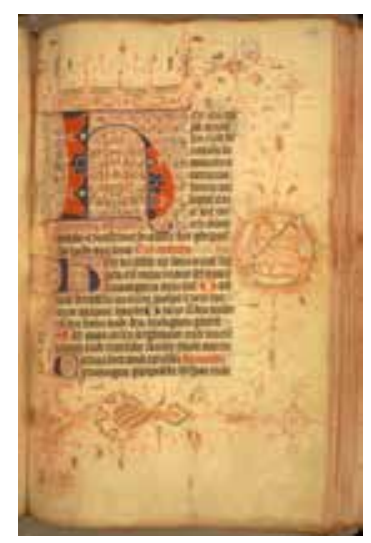

Fig. 39 Incipit of the Hours of the Cross, with a Lamb of God roundel painted in the margin. Leiden Universiteitsbibliotheek, Ms Ltk 1985, fol. 82r (artwork in the public domain)

26 Badges could be inserted near prayers associated with Communion-but also at moments that focused on the body of Christ, where they could do the most work. It is perhaps for this reason that several Lamb of God roundels are affixed at the Hours of the Cross and at the Hours of the Passion, texts the votary would read to commemorate (and mentally re-enact?) the suffering inflicted on Christ's body. These texts became popular locations for votaries to attach their round metal badges and for painters to represent the Lamb of God with its sacramental connotations.

1. A book of hours from the Southern Netherlands has a Crucifixion miniature to preface the Hours of the Cross, and an owner sewed two or more round badges to its margins (Brussels, Koninklijke Bibliotheek, Ms 10541, fol. 10v; fig. 25). The owner therefore surrounded the painted image of the body of Christ with other images in a different medium, drawing a link between the two. 
2. A small book of hours made in Delft around 1440 had very small round badges sewn in at the end of Hours of the Passion (Cambridge, Fitzwilliam Museum, Ms 135, fol. 32v; fig. 26). The owner avoided sewing the badge(s) on top of the painted and gilt decoration applied to most of the text pages (Cambridge, Fitzwilliam Museum, Ms 135, fol. 23r; fig. 27). She or he therefore utilized the blank space at the end of the text to sew them. The most prominent roundel was $14 \mathrm{~mm}$ in diameter and was sewn in so that it appeared at the bottom of $32 \mathrm{v}$, beneath the Hours of the Passion, as if placing the body of Christ within the text. The badge(s) was/were probably removed in the eighteenth century when the manuscript was trimmed for rebinding.

3. A book of hours made in South Holland around 1485 is unusual in that it contains both the Long Hours of the Cross and the Short Hours of the Cross (The Hague, Koninklijke Bibliotheek, Ms BPH 137). What is even more interesting is that the owner has placed badges at the incipits of both. At the Long Hours of the Cross, the first major text in the manuscript (fols. 13v-14r; fig. 28), the owner inserted a round badge, presumably a Eucharist badge, at the upper corner of the opening. Backlighting indicates that the owner sewed the top and bottom of the badge to the page (fig. 29). The Short Hours of the Cross appears later in the same manuscript, this time with only penwork decoration and no miniature; again, the owner inserted a round badge to the top corner of the incipit (fig. 30). Heavy thread is still visible on the back of the leaf, while the badge itself would have adorned the marginal area just beyond the penwork decoration of the folio (fig. 31). The badge made an indelible impression on the facing folio.

4. A parchment badge with the Lamb of God roundel survives, affixed to a blank page facing the incipit of the Hours of the Cross in a book of hours from Haarlem, ca. 1450 (olim Delft, Prinsenhof, fols. 52v-53r; fig. 32). The manner with which the roundel has been affixed to the page also contributes to its meaning, as the owner used a needle and thread to tack the roundel at four points. Perhaps the owner likened these four punctures with the needle to the four nails with which Jesus was hung on the cross. Indeed, on the recto side of the folio, one can see that the threads have formed a cruciform shape, as if the body of Christ had symbolically been crucified on parchment with silk. ${ }^{26}$

5. A modest book of hours in Latin, made in the Southern Netherlands, has needle holes from where a badge was sewn in, just above the incipit to the Hours of the Cross (The Hague, Meermanno Museum, Ms 10 F 15; fig. 33).

6. A roundel was sewn into a book of hours from Delft in the upper margin above a full-page miniature depicting Christ crucified, in other words, the body of Christ. (The Hague, Koninklijke Bibliotheek, Ms 135 E 22, fol. 103v; fig. 34). This miniature also marks the incipit of the Hours of the Cross. The impression is faint, and the holes are easier to see on the verso of the image (fig. 35). The holes show how the object was sewn on with four stitches, similar to the stitches in the Prinsenhof manuscript. Later in the same manuscript, but still within the Hours of the Cross, an illuminator from 
Delft added a small image depicting the Lamb of God in the otherwise penwork-decorated margin (fig. 36). Was the illuminator here commenting on votaries' penchant for storing Eucharistic objects within this text?

7. Likewise, a book of hours from Arnhem (in the eastern part of the Northern Netherlands) has a painted Lamb of God roundel in the margin to mark the Short Hours of the Cross (olim Nijmegen, Jezuitenbibliotheek Berchmanianum, Ms 5000 A 30; fig. 37). ${ }^{27}$ The book was heavily trimmed when it was rebound, and the lamb's legs have been cut off. Convent sisters, who usually avoided making figurative imagery, may have made this book. They could have copied the Lamb of God medallion from a Eucharist badge and the blue columbines from a model book. In this way, the badges may have served as something akin to printed models that illuminators used to increase their repertory of imagery.

8. Many books of hours included painted decoration that closely resembles Eucharist badges in the margin of the manuscript. For example, a book of hours made by the canonesses regular of Saint Agnes in Delft includes the Lamb of God in a roundel of the crown of thorns at the incipit of the Short Hours of the Cross (Oxford, Bodleian Library, Douce Ms 248, fol. 66r; fig. 38).

9. In a book of hours illuminated in North Holland, the illuminator depicted a radiant trotting lamb in the margin at the Hours of the Cross (Leiden, Universiteitsbibliotheek, Ms Ltk 1985, fol. 82r; fig. 39). This might be construed as a reference to the common practice of sewing in analogous metallic imagery at this point in the book.

\section{With Incarnational Themes}

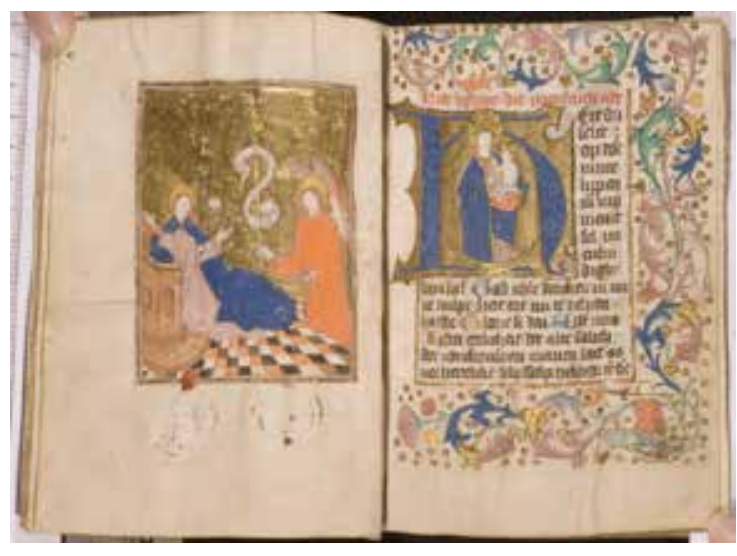

Fig. 40 Incipit of the Hours of the Virgin, with a full-page miniature depicting the Annunciation, and the offsets of two round badges at the lower margin. Utrecht, Catharijneconvent, Ms BMH h63, fols. 16v-17r (artwork in the public domain; photo: Byvanck Genootschap)

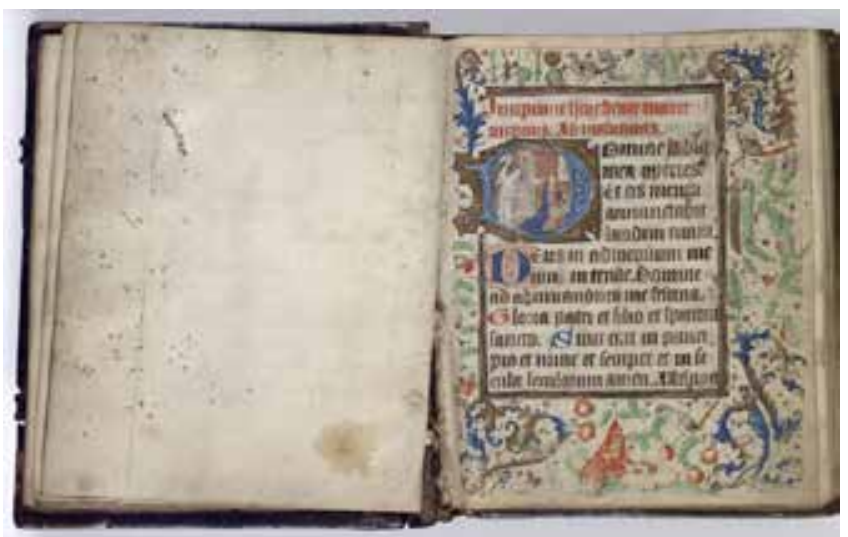

Fig. 41 Leaf ruled for an image (never filled in) with at least eighteen more round offsets on a blank leaf prefacing the Hours of the Virgin. The Hague, Koninklijke Bibliotheek, Ms 74 G 5, fols. 13v-14r (artwork in the public domain) 


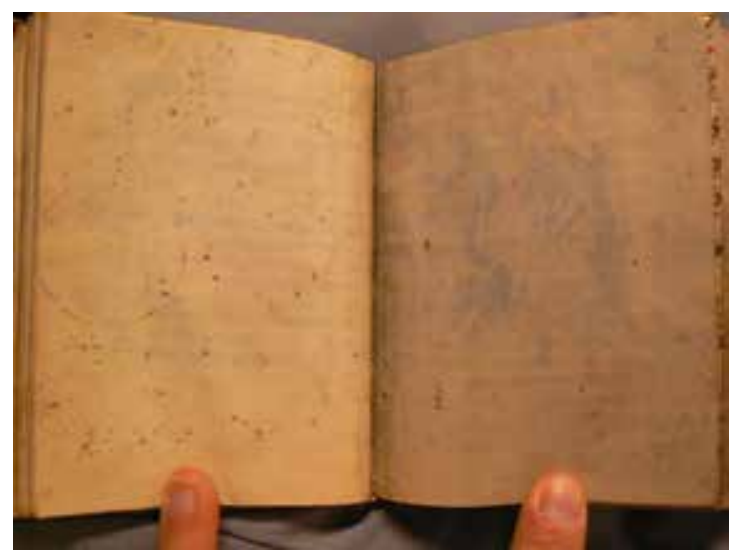

Fig. 42 Blank opening before the Hours of the Virgin. The Hague, Koninklijke Bibliotheek, Ms 74 G 35, fols. 13v-14r (artwork in the public domain; photo by the author)

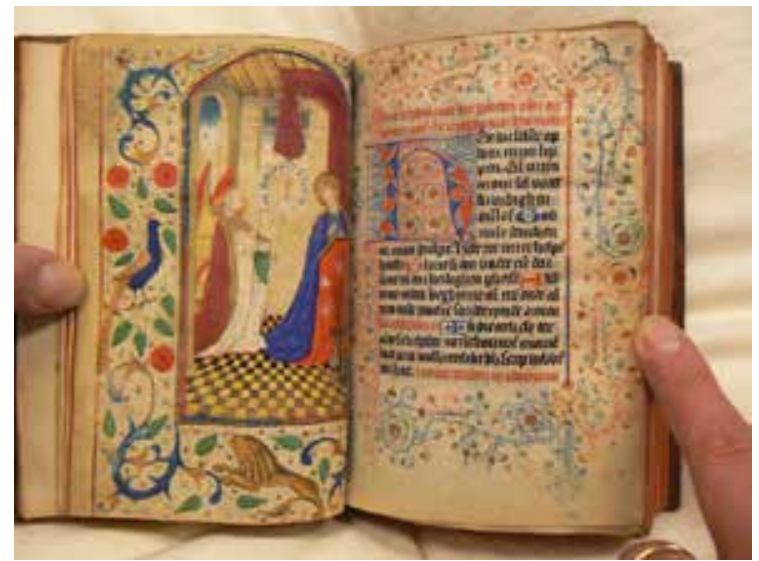

Fig. 44 Hours of the Virgin, with the offset of a round badge at the upper corner. The Hague, Meermanno Museum, Ms $10 \mathrm{~F}$, fols. $14 \mathrm{v}-15 \mathrm{r}$ (artwork in the public domain; photo by the author)

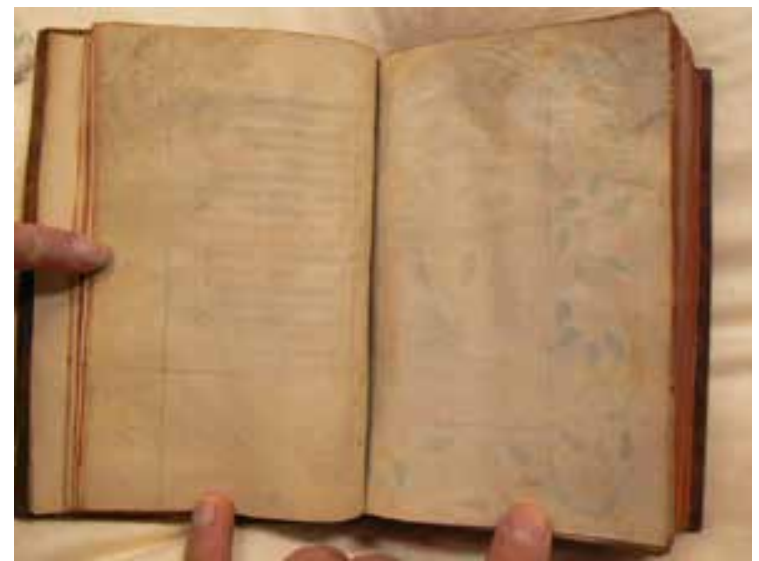

Fig. 46 Folio formerly prefacing the Hours of the Virgin (before the full-page Annunciation was added), with the offset of a round badge at the upper corner. The Hague, Meermanno Museum, Ms 10 F 2, fol. $13 \mathrm{v}$ (artwork in the public domain; photo by the author)

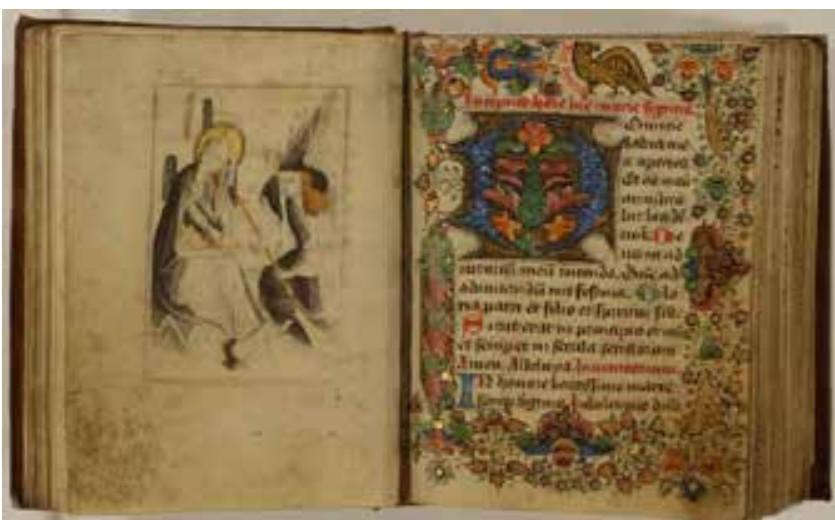

Fig. 43 Incipit of the Hours of the Virgin. The Hague, Koninklijke Bibliotheek, Ms $74 \mathrm{G} 35$, fols. $14 v-15 r$ (artwork in the public domain)

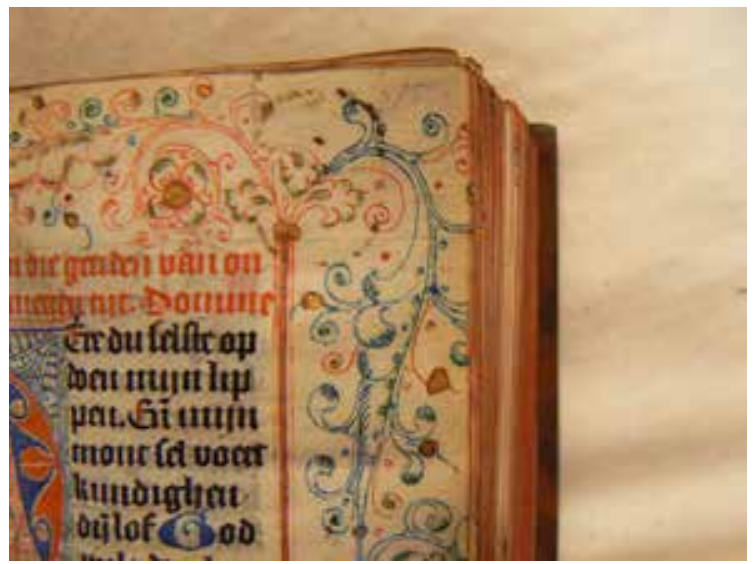

Fig. 450 ffset of a round badge (detail of fig. 44: fol. 15r) (photo by the author)

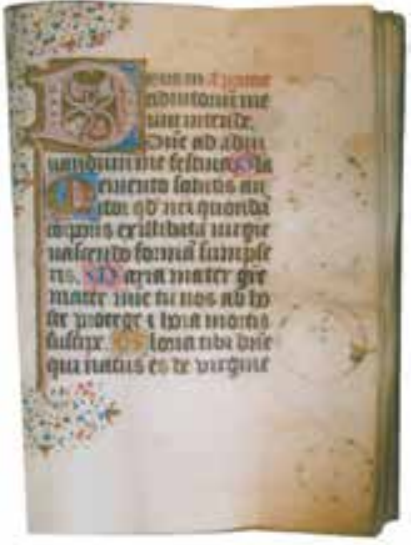

Fig. 47 Prime within the Hours of the Virgin. Bruges, Stadsbibliotheek, Ms 329, fol. 62r (artwork in the public domain; photo: Hanneke van Asperen) 


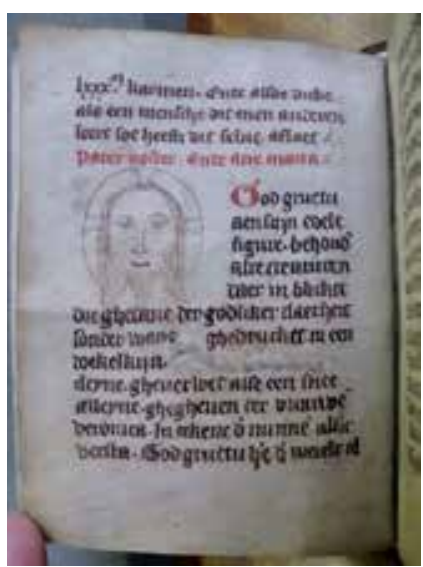

Fig. 48 Drawing of the face of Christ. Ghent, Universiteitsbibliotheek, Ms 1353, fol. 114v (artwork in the public domain; photo: the author)

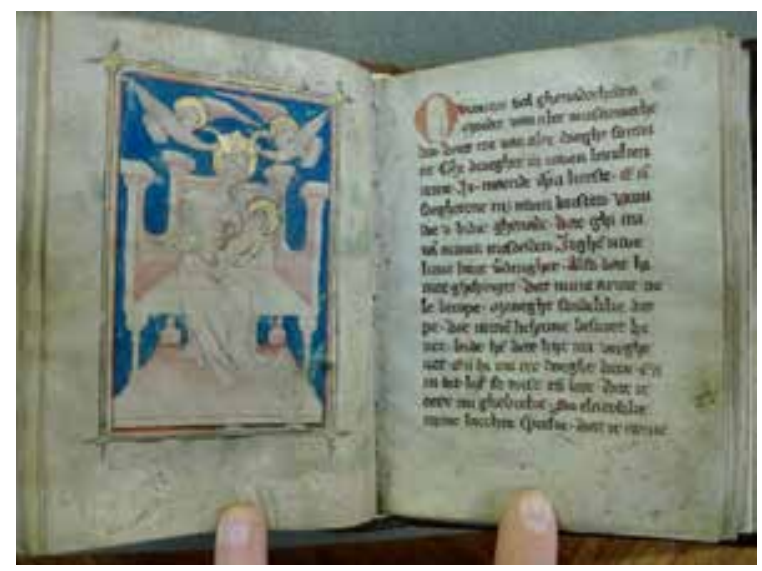

Fig. $50 \mathrm{~A} \mathrm{painting} \mathrm{depicting} \mathrm{the} \mathrm{Virgin} \mathrm{and} \mathrm{Child} \mathrm{(added} \mathrm{to} \mathrm{this} \mathrm{prayer}$ book of ca. 1394 in the fifteenth century). Ghent, Universiteitsbibliotheek, Ms 1353, fols. 116v-117r (artwork in the public domain; photo by the author)

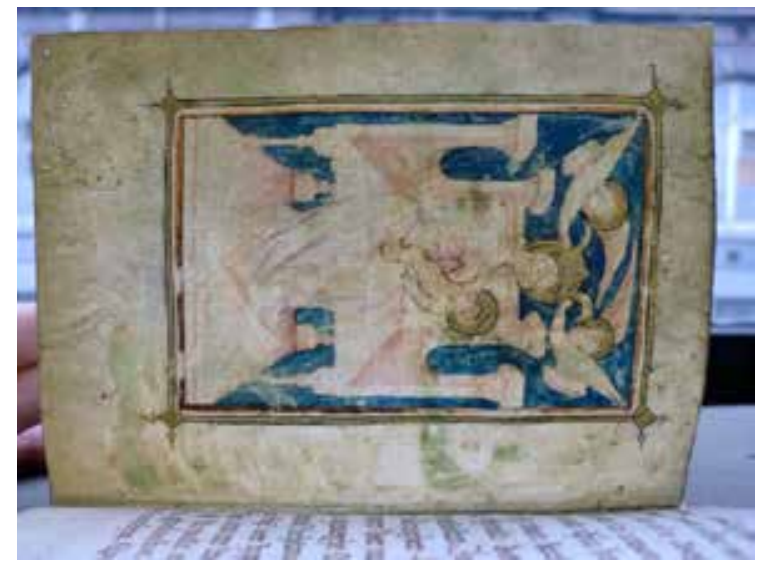

Fig. 52 Needle holes shown in fig. 51, seen with backlighting (photo by the author)

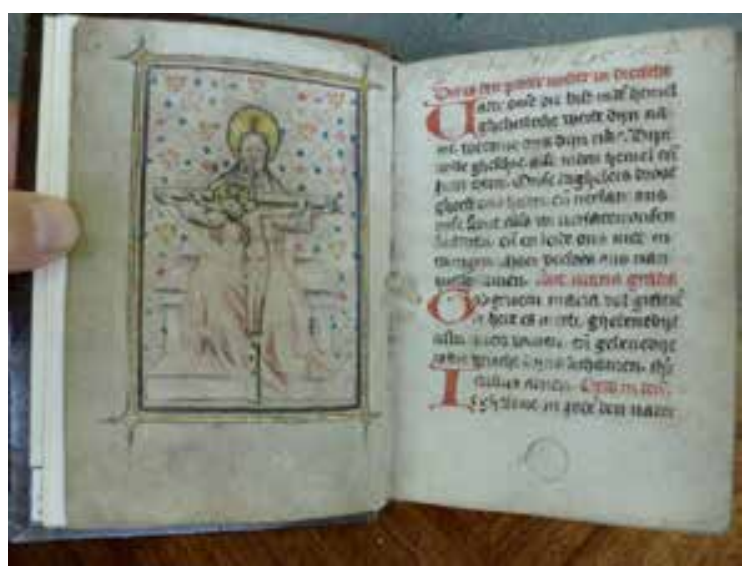

Fig. $49 \mathrm{~A}$ painting depicting the Trinity (added to this prayer book of ca. 1394 in the fifteenth century). Ghent, Universiteitsbibliotheek, Ms 1353 , fols. 2v-3r. (artwork in the public domain; photo by the author)

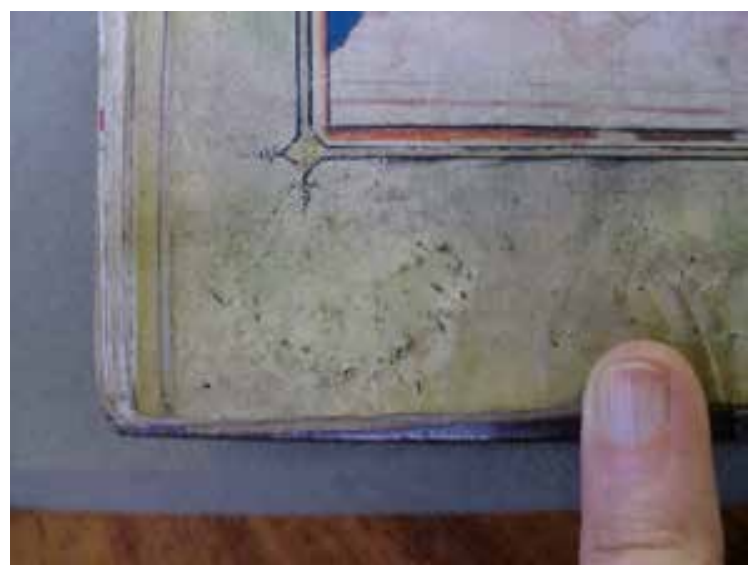

Fig. 51 Detail of fig. 50 (fol. 116v) showing needle holes (photo by the author)

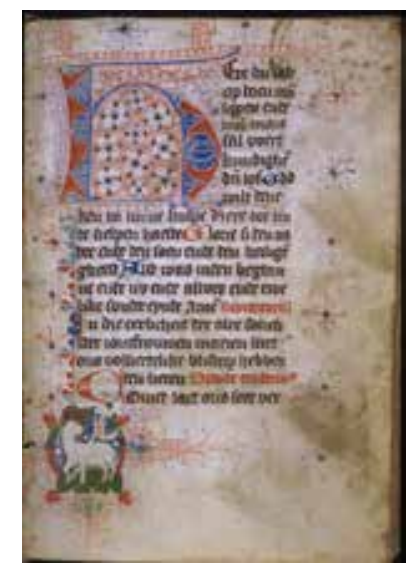

Fig. 53 Incipit of the Hours of the Virgin, with a Lamb of God roundel in the margin. Tilburg, Universiteitsbibliotheek, Haaren 4, fol. 15r (artwork in the public domain; photo: Byvanck Genootschap) 
27 Because the host was considered the "enfleshing" of substance, one can easily see how the Incarnation (the implantation of God in the womb of Mary) was likened to the "enfleshing" of the bread, as both made the body of Christ manifest on earth. Consequently, Eucharist badges, or their offsets, appear frequently juxtaposed with images of the Annunciation and within the Hours of the Virgin, which tells the story of the Christ's infancy. Adding the Eucharist to the image of the Virgin Annunciate reasserts the idea of God's presence on earth, first through Mary's conception, and thereafter via the transubstantiation of the host. The host provided a tangible manifestation of the Incarnation. A large number of retables (objects that stood on the altar and formed a backdrop to the drama of the transubstantiation) depict the Annunciation, because it represents the appearance of God in fleshly form on earth, and therefore mirrors the creation of flesh in the wafer. While Christians routinely took Communion at Easter, the most enthusiastic devotees may have also taken it at the Feast of the Annunciation and Feast of the Nativity, commemorations which celebrate the presence of Christ on earth.

1. In a book of hours from the IJssel region, there are two round offsets juxtaposed with the body of Mary as she receives the body of Christ internally (Utrecht, Catharijneconvent, Ms BMH h63, fols. 16v-17r; fig. 40). These offsets appear at the bottom of a miniature depicting the Annunciation, as if the book owner were making the presence of Jesus more tangible. The body of Christ is still visible in the impression in the soft parchment in the offset on the left. Both badges have been affixed with red silk thread, as if the act of affixing them were a ceremonious event. Stitches would have framed and called attention to the added material.

2. A book of hours in The Hague (Koninklijke Bibliotheek, Ms 74 G 5) has offsets of badges on a blank flyleaf (see fig. 3 above), as well as at least eighteen more round offsets on a blank leaf prefacing the Hours of the Virgin (fols. 13v-14r; fig. 41). Some of these badges overlapped, as if the owner wanted to cover every square centimeter with metallic Eucharists. The folio prefacing the Hours of the Virgin was left uninscribed but ruled with a frame to indicate where an image commensurate with the text block should be added. While the owner never had the image painted in, he or she may have affixed an image to the folio's center by stitching its corners to the parchment. The owner then preceded to fill the periphery with round badges - what I surmise were Eucharist badges. These would have faced the incipit of the Hours of the Virgin, with its five-line initial depicting the Annunciation. It is possible that votaries could have also had the opportunity to take Communion on the Feast of the Annunciation on March 25. The badges would not only have made the incarnational theme of the Annunciation complete on the page but would also have made the text easy to find, which of course is another function of decoration.

3. Similarly, an owner of a book of hours from Delft stuffed the full blank opening leaf before the Hours of the Virgin with round badges of various dimensions (The Hague, Koninklijke Bibliotheek, Ms 74 G 35, fols. 13v-14r; fig. 42). Although the back of the Annunciation miniature is also blank, the owner chose to sew the badges onto the preceding folio instead, for one of two reasons. Either the owner did not want to risk injuring the image of the Annunciation by sewing badges to it (fig. 43), or else it was 
the first owner who sewed in the badges, and a second or later owner who added the full-page grisaille images. As such, either a single owner or a series of owners added physical material, incarnational badges and imagery, to the incipit of the Hours of the Virgin.

4. Likewise, a book of hours made in South Holland (probably Delft) originally only contained penwork decoration before one or more owners embellished it with fullpage miniatures and badges. For example, someone added a full-page painted Annunciation, which does not match the original penwork and thus was made in a separate campaign of work (The Hague, Meermanno Museum, Ms 10 F 2, fols. 14v-15r; fig. 44). There is an offset from a round badge on the upper-right corner of the text page (fig. 45). There is no offset from this badge on the facing folio, the miniature. However, there is an offset (or possibly two) on the previous folio (fol. 13v; fig. 46). This suggests that an early owner added the badge(s) to personalize the book, which at that point contained only penwork decoration. Later, another owner upgraded the manuscript by adding full-page miniatures to the major text openings but at the same time removed the badges, which belonged to someone else's memory system.

5. An owner of a book of hours (for Use of Tournai) made in Northern France or the francophone Southern Netherlands filled the outer margins of some folios within the Hours of the Virgin with round badges (Bruges, Stadsbibliotheek, Ms 329, fol. 62r; fig. 47). ${ }^{28}$ For example, the incipit for prime has at least five round badge offsets in the outer margin. Some of them overlap, which suggests that the owner desperately wanted to affix the badges to this particular page. While it remains possible that these badges were Marian, the repeated round shapes in several sizes are consistent with the large number of Eucharist badges I introduced earlier.

6. A prayer book in Dutch, made in South Brabant in or around 1394 has an indulgenced image of the face of Christ, looking as round as a Eucharist wafer, crudely drawn onto a text folio (Ghent, Universiteitsbibliotheek, Ms 1353, fol. 114v; fig. 48). In the fifteenth century, someone added two more folios bearing full-page paintings (figs. 49 and 50). In addition to adding the images, this or another owner (probably again in the fifteenth century) sewed at least two round badges to the bottom margin of the painting representing the Virgin and Child (fig. 51). When photographed with backlighting (fig. 52), the leaf reveals more needle holes near the top: apparently someone sewed a curtain to this image in order to play a game of revelatio with the image, revealing not only the image of the Incarnation, but a replica Eucharist-a replica of the Body of Christ-right on the page.

7. Sometimes illuminators added analogous imagery at the Hours of the Virgin, as if commenting on the cultural practice of adding "memory" badges to a prayer book. A book of hours now in Tilburg (Universiteitsbibliotheek, Haaren 4, fol. 15r) has a painted Lamb of God at the incipit of the Hours of the Virgin, which is the place in the manuscript usually reserved for a depiction of the Annunciation, at least in manuscripts that are provisioned with full-page miniatures. Here the simple Lamb of God 
seems to summarize the incarnational theme (fig. 53).

\section{At the Penitential Psalms and Litany of the Saints}

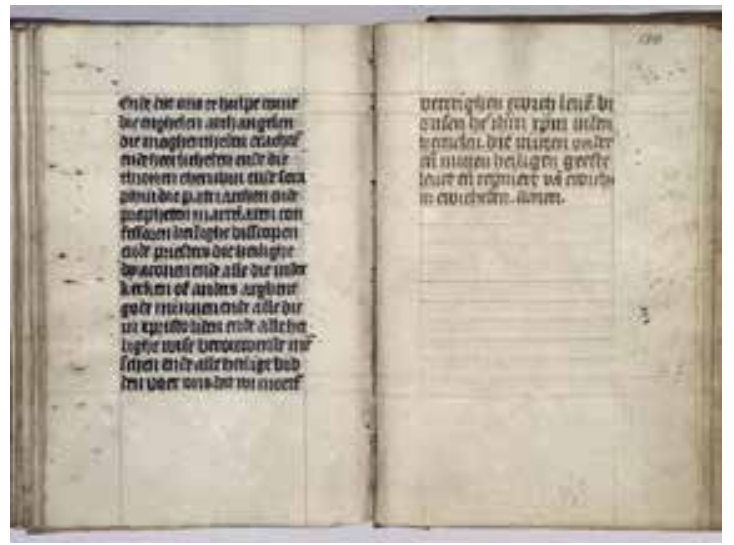

Fig. 54 The end of the Seven Penitential Psalms and Litany of the Saints, with offsets from at least seven round badges. The Hague, Koninklijke Bibliotheek, Ms 133 M 23, fols. 129v-130r (artwork in the public domain)

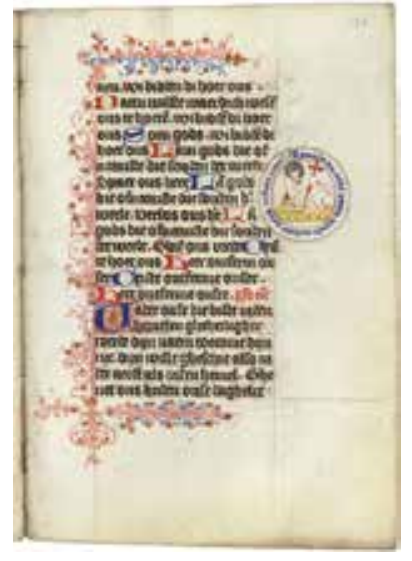

Fig. 56 Lamb of God roundel illusionistically painted in the margin on a page at the end of the "ut" and "per" statements (the end of the Litany of the Saints). The Hague, Koninklijke Bibliotheek, Ms $135 \mathrm{~F} 2$, fol. 136r (artwork in the public domain)

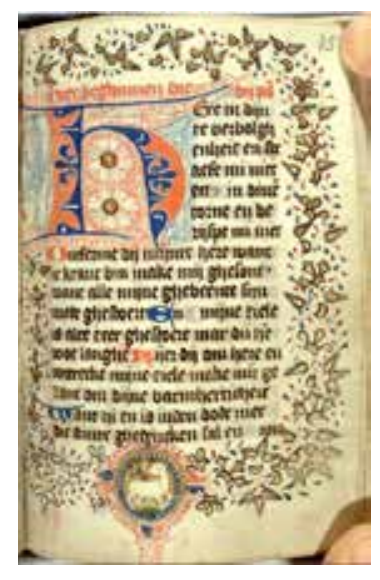

Fig. 58 Lamb of God roundel painted at the lower margin of the incipit of the Seven Penitential Psalms. Retz, Stadtarchiv, Inv. no. 65/23 (artwork in the public domain)

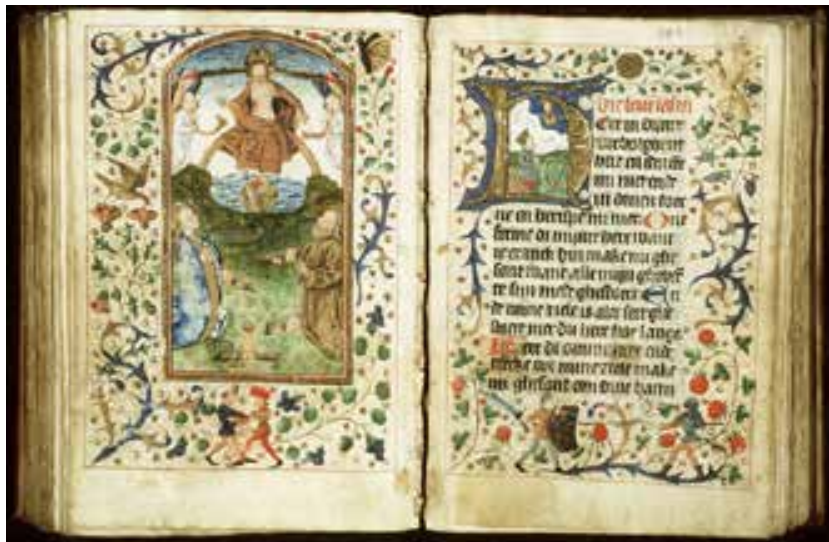

Fig. 55 Incipit of the Seven Penitential Psalms and Litany of the Saints. The Hague, Koninklijke Bibliotheek, Ms 133 M 23, fols. 105v-106r (artwork in the public domain)

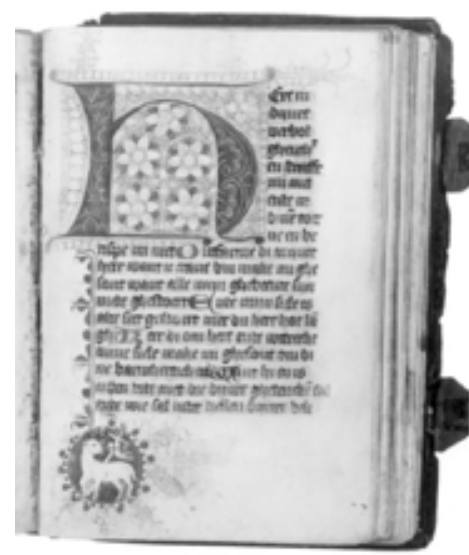

Fig. 57 Lamb of God roundel painted at the lower margin of the incipit of the Seven Penitential Psalms. Utrecht, Catharijneconvent, Ms ABM h58, fol. 121r (artwork in the public domain; photo: Byvanck Genootschap)

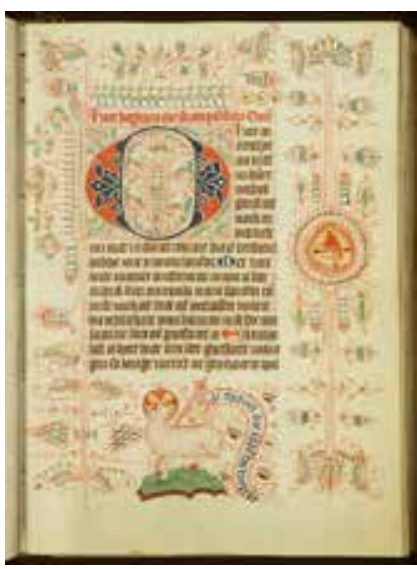

Fig. 59 Incipit of the Seven Penitential Psalms. The Hague, Koninklijke Bibliotheek, Ms 78 J 7, fol. 73r (artwork in the public domain) 
According to the Christian tradition, the Lamb of God atones for the sins of all mankind and redeems them. This idea is implicit in the words "Agnus Dei, qui tollis peccata mundi, miserere nobis" (Lamb of God, Who taketh away the sins of the world, have mercy on us)." These words often surround the Lamb of God in Dutch translation in the images under consideration in this article. The words, attributed to John the Baptist, were also repeated by the priest near the end of the Canon of the Mass. Such exculpation of sin was strongly associated with penance, and with the Seven Penitential Psalms, one of the standard texts in all books of hours. The Seven Penitential Psalms are always followed by the Litany of the Saints, in which the reader asks for intervention from a long list of saints, beginning with the archangels and ending with the virgin saints. In other words, Eucharist badges appear at the Penitential Psalms and Litany, the supreme prayers of asking forgiveness.

29 I suggest that votaries read the Seven Penitential Psalms primarily during Lent, the time of atonement. Lent occupies the forty days before Easter and like Passion week-when the Hours of the Cross and the Hours of the Passion may have been read intensively-culminates in Easter. The offsets of many round badges are imprinted at this position in several books of hours. Votaries apparently wanted to associate consuming the host with penance and the exculpation of sins. Reading these Psalms formed a step toward contrition and the expiation of sin. Including the Lamb of God roundels contributed to that function.

1. A book of hours made in Delft or South Holland has a selection of offsets from round metal objects (The Hague, Koninklijke Bibliotheek, Ms 133 M 23, fols. 129v-130r; fig. 54). These offsets come at the end of the Litany, and there are traces of the green thread with which they were sewn. Because there was very little space available at the beginning of the text (fig. 55), which has full painted borders, the owner has chosen to insert them at the end of the text, where there was a blank opening. The badges were probably removed when the manuscript was rebound, as the binder severely trimmed the edges before rebinding, probably because the edges were filthy with wear. That the manuscript was soiled makes sense, as its owner apparently had a sustained and highly physical relationship with it. ${ }^{29}$

The other examples of round Lamb of God images have all been painted by an illuminator, rather than sewn in physically. I include them because they seem to reflect upon the cultural practice of sewing in badges.

2. One of the most spectacular roundels appears painted into a book of hours from Delft, possibly by the sisters of Saint Agnes (The Hague, Koninklijke Bibliotheek, Ms 135 F 2, fol. 136r; fig. 56). The Lamb of God roundel is painted onto a page at the end of the "ut" and "per" statements (the end of the Litany of the Saints). As the calendar has a table for calculating the date of Easter that begins with 1453, it is likely that this manuscript dates from that year (although it is also possible that the manuscript copies an exemplar made in that year). The roundel is painted illusionistically, is if it were a separate object that overlapped the text on the page.

3. In several books of hours made in the eastern part of the Northern Netherlands, a 
painted Lamb of God roundel appears at the lower margin of the incipit of the Seven Penitential Psalms. One of these is in Utrecht (Catharijneconvent, Ms ABM h58, fol. 121r; fig. 57).

4. Another Lamb of God appears at the lower margin of the incipit of the Seven Penitential Psalms in a manuscript made in the eastern part of the Northern Netherlands, possibly in Arnhem (Retz, Stadtarchiv, inv. no. 65/23; fig. 58). ${ }^{30}$

5. Another Lamb of God prances in the lower margin of the incipit of the Seven Penitential Psalms in a manuscript made in North Holland, probably near Amsterdam, with its phantasmagoric yet geometrically controlled penwork (The Hague, Koninklijke Bibliotheek, Ms 78 J 7, fol. 73r; fig. 59).

30 In sum, I suggest that votaries attached Eucharist badges to their manuscripts at the Penitential Psalms and Litany of the Saints because the intense reading of these texts culminated at Easter. Their placement within the book is related to the rituals surrounding Communion.

\section{E. In multiple Places in the Manuscript}

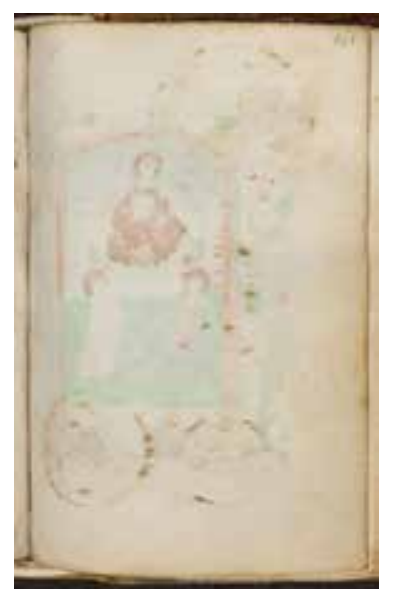

Fig. 60 Reverse of Last Judgment print, inserted to preface the Seven Penitential Psalms, with needle holes from round badges formerly attached to the print. Brussels, Koninklijke Bibliotheek, Ms IV 142, fol. $101 \mathrm{r}$ (artwork in the public domain; photo by the author)

Fig. 62 Reverse of Annunciation print, inserted to preface the Hours of the Virgin, with offset of a round badge formerly attached to the blank back of the print. Brussels, Koninklijke Bibliotheek, Ms IV 142 , fol. $14 r$ (artwork in the public domain; photo by the author)

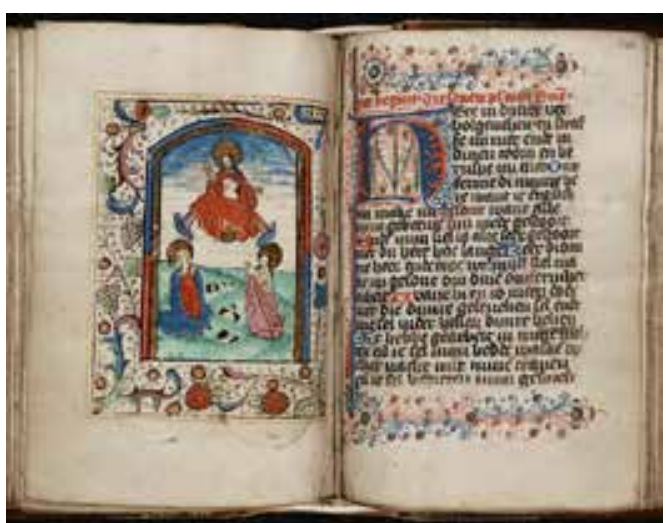

Fig. 61 Last Judgment print, inserted to preface the Seven Penitential Psalms, with offsets from round badges formerly sewn to the back of the print. Brussels, Koninklijke Bibliotheek, Ms. IV 142, fols. 101v-102r (artwork in the public domain)

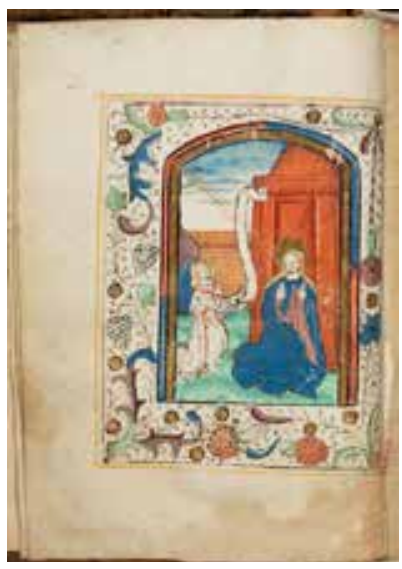

Fig. 63 Annunciation print, inserted to preface the Hours of the Virgin. Brussels, Koninklijke Bibliotheek, Ms IV 142, fol. 14v (artwork in the public domain; photo by the author) 


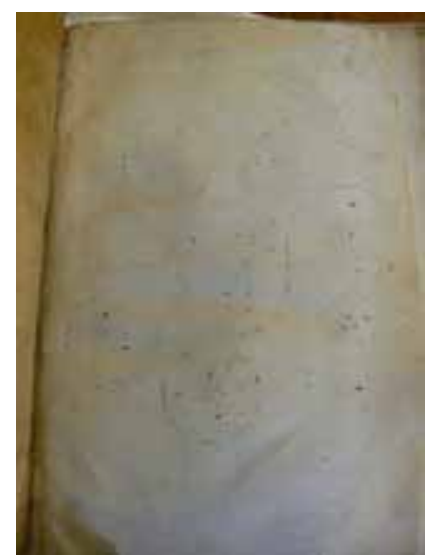

Fig. 64 Final flyleaf, with at least eight round offsets. Liège, University Library, Ms Wittert 32 (artwork in the public domain; photo by the author)

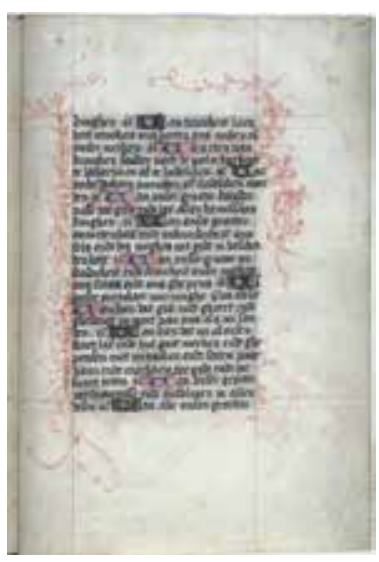

Fig. 65 Folio within the Penitential Psalms, with a round offset (?) at upper margin. Liège, University Library, Ms Wittert 32, fol. 144r (artwork in the public domain; photo: Byvanck Genootschap)

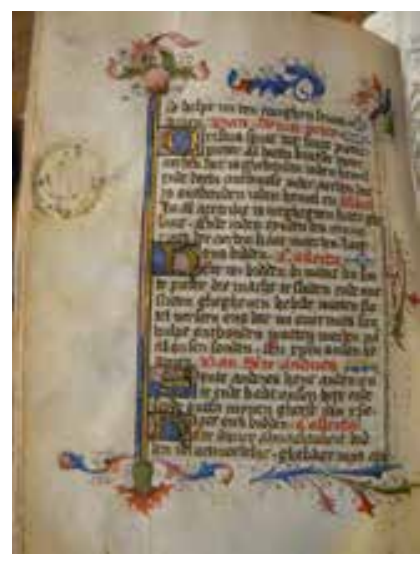

Fig. 66 Folio with the suffrage to Saint Peter, with a round offset at the side margin. Liège, University Library, Ms Wittert 32, fol. 116v (artwork in the public domain; photo by the author)

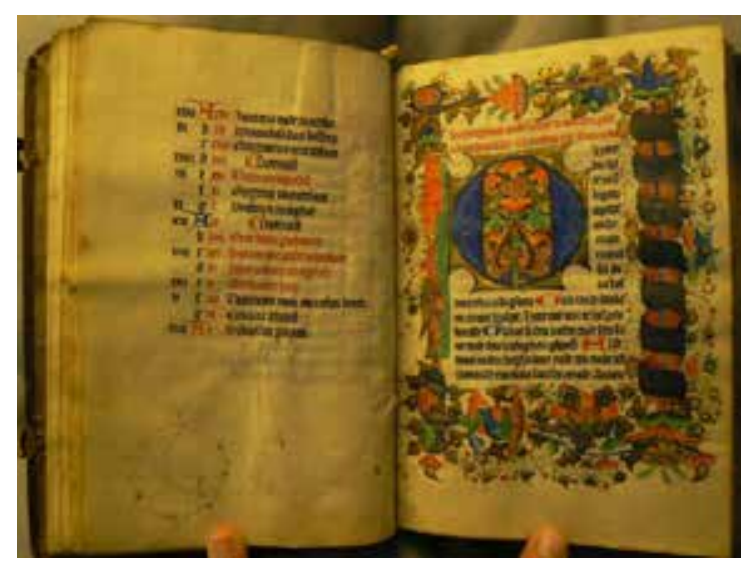

Fig. 67 Incipit of the Hours of the Virgin, with offsets of round badges on the facing folio. Utrecht Universiteitsbibliotheek, Ms 15 ( 9, fols. $20 \mathrm{v}-21 \mathrm{r}$ (artwork in the public domain; photo by the author)

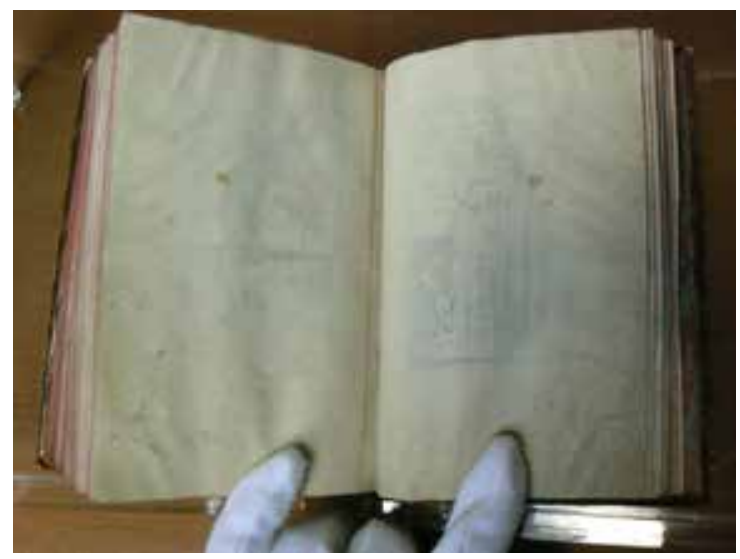

Fig. 69 The blank backs of two grisaille miniatures, with offsets of round badges on the left-hand folio. Antwerp, Plantin Museum, Ms 14.19, fols. 171v-172r (artwork in the public domain; photo by the author)

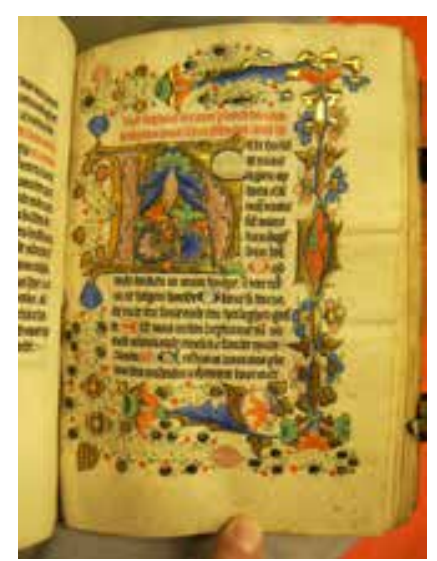

Fig. 68 Incipit of the Hours of the Cross, with a single offset of a round badges at the lower corner. Utrecht, Universiteitsbibliotheek, Ms $15 \mathrm{C}$ 9, fol. $95 \mathrm{r}$ (artwork in the public domain; photo by the author)

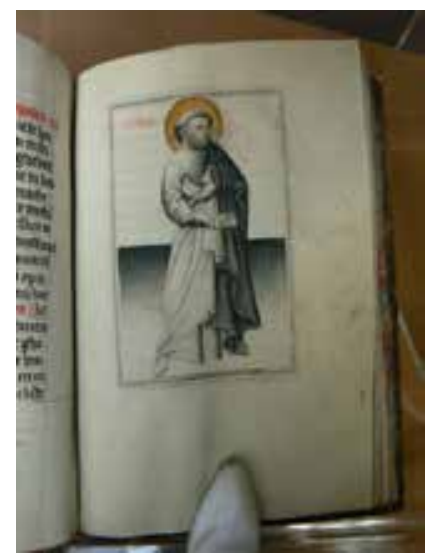

Fig. 70 Grisaille miniature of Saint Peter, with offsets of round badges in the margin. Antwerp, Plantin Museum, Ms 14.19, fol. 168r (artwork in the public domain; photo by the author) 


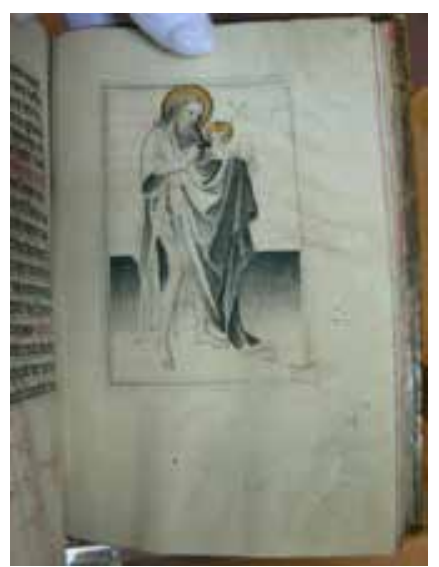

Fig. 71 Grisaille miniature of Saint John the Baptist, with offsets of round badges on the back. Antwerp, Plantin Museum, Ms 14.19, fol. 171r (artwork in the public domain; photo by the author)

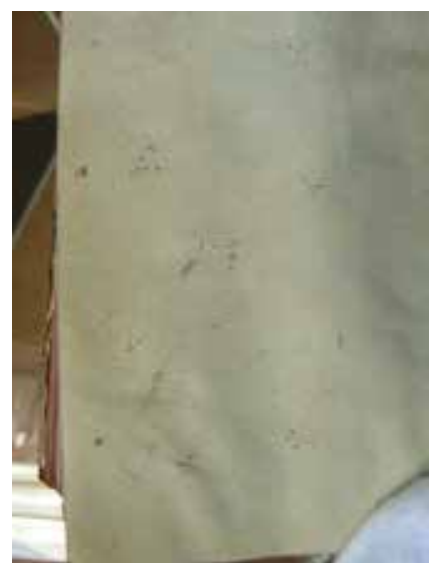

Fig. 72 Grisaille miniature of Saint John the Baptist, with offsets of round badges on the back. Antwerp, Plantin Museum, Ms 14.19,

fol. 171v (artwork in the public domain; photo by the author)

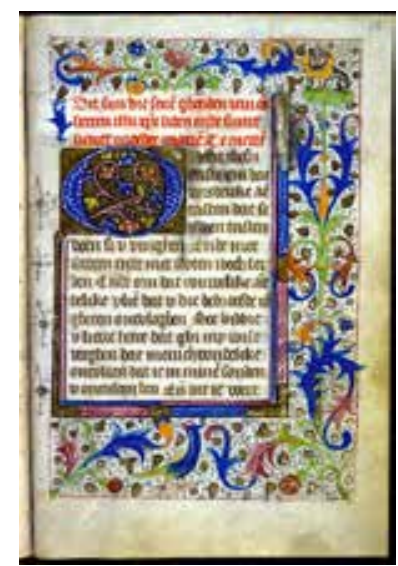

Fig. 73 Hours of the Passion and of His Dear Mother Mary. Nijmegen, Universiteitsbibliotheek, Ms 320, fol. 14 r (artwork in the public domain; photo: Byvanck Genootschap)

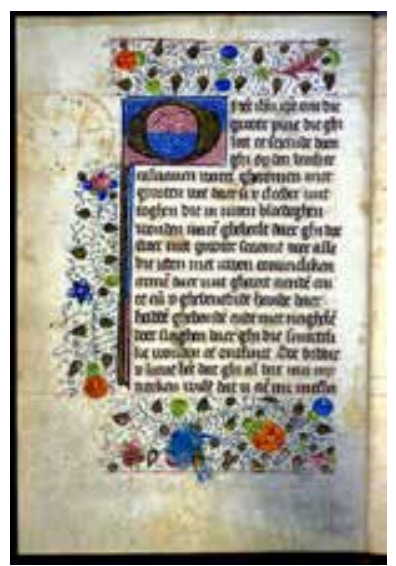

Fig. 74 Sext of the Hours of the Passion and of His Dear Mother Mary. Nijmegen, Universiteitsbibliotheek, Ms 320, fol. 18v (artwork in the public domain; photo: Byvanck Genootschap)

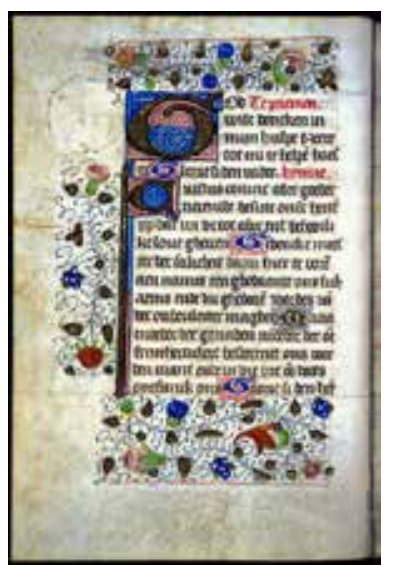

Fig. 75 Prime of the Hours of the Virgin. Nijmegen, Universiteitsbibliotheek, Ms 320, fol. 44v (artwork in the public domain; photo: Byvanck Genootschap)

31 As the discussion above indicates, votaries associated Eucharist badges with several different texts and images. Accordingly, some votaries sewed in badges at multiple places within their books. This may reflect their having taken the Eucharist not just at Easter but at other times of the year as well.

1. A rather strange book of hours from Delft may have come from the convent of Saint Anne (a young and poor convent dedicated to Saint Augustine) (Brussels, Koninklijke Bibliotheek, Ms IV 142). The sisters may have written the manuscript, but they apparently did not have an illuminator in house, and to add images to their manuscript, they bound in hand-painted woodcut prints. A print depicting the Last Judgment prefaces the Penitential Psalms and was blank on the back. That spot was chosen by the book's owner for the addition of at least five (and possibly seven) round badges (fol. 101r; fig. 60). In this position, they are as physically close to the judging Christ as 
possible, separated only by a sheet of semitranslucent parchment (fig. 61). In the same manuscript a single round offset, with corresponding needle holes, appears on the reverse of the Annunciation image, another hand-painted inserted print (figs. 62 and 63). Thus the votary may have added the badges because the space was available, because she (or he) wanted to associate the body of Christ with these images, or because they made the book sections easier to locate.

2. A book of hours made in the Eastern part of the Northern Netherlands, ca. 1480-1500 (Liège, University Library, Ms Wittert 32) had round badges inserted on at least two and possibly three folios. On the final flyleaf the owner inserted at least eight round metal badges (fig. 64). That owner also may have sewn a badge onto fol. 144, which is in the middle of the Penitential Psalms (although the offset is difficult to see; fig. 65). And finally, in the suffrages, he or she has attached one round metal badge next to the Suffrage to Peter (fol. 116v; fig. 66). It is possible that the reader was marking his name saint.

3. A book of hours written at the Convent of Saint Margaret in Gouda but illuminated at the convent of Saint Agnes in Delft was also owned by someone who added badges to multiple places in the manuscript (Utrecht Universiteitsbibliotheek, Ms 15 C 9). She or he sewed some in the lower margin to preface the Hours of the Virgin (fols. 20v-21r; fig. 67) and also added a badge at the incipit of the Hours of the Cross (fol. 95r; fig. 68). With these juxtapositions the owner exploited both the Christological and incarnational themes inherent in the host.

4. A book of hours with so-called Delft grisailles had badges sewn onto the blank parchment on the backs and in the margins of two full-page miniatures within a section of suffrages (Antwerp, Plantin Museum, Ms 14.19, fols. 171v-172r; fig. 69). Specifically, the owner added several round badges to the image of Saint Peter (fol. 68r; fig. 70 and several more to the image of John the Baptist (fol. 171r and v; figs. 71and 72). Why the owner singled out Saint Peter is open to conjecture. He or she may have chosen the area around John the Baptist because he is pointing to the Lamb of God and therefore played a role in Eucharistic devotion.

5. A rather odd book of hours, which may have been made in Bruges but spent some time in the convent in Wittem near the Netherlands-German border, contains a seldom-copied text: the Hours of the Passion and of His Dear Mother Mary (Nijmegen, Universiteitsbibliotheek, Ms 320, fol. 14r; fig. 73). Apparently the owner responded strongly to this text, for he or she affixed a round badge on fol. $18 \mathrm{v}$, for sext, where holes reveal where it was sewn in (fig. 74). The owner also inserted a round badge on fol. 44v, for prime, in the Hours of the Virgin (fig. 75). A precise pattern explaining these insertions eludes me. (This manuscript deserves to be better known; among other texts, it contains a prayer to be recited after bathing.)

\section{F. Wherever There Is a Blank Page Available}




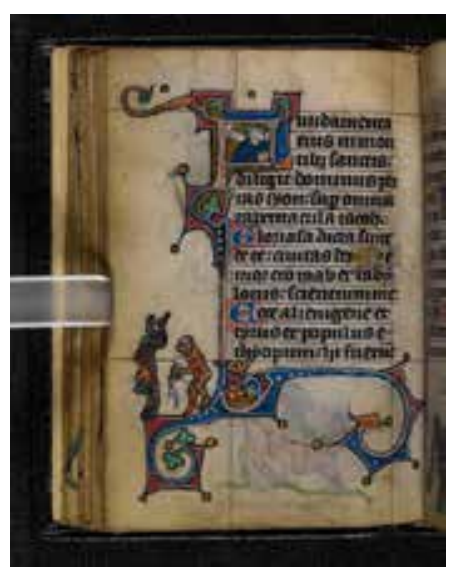

Fig. 76 Folio with painted borders typical of this manuscript. London, British Library, Stowe Ms 17, fol. 35v (artwork in the public domain)

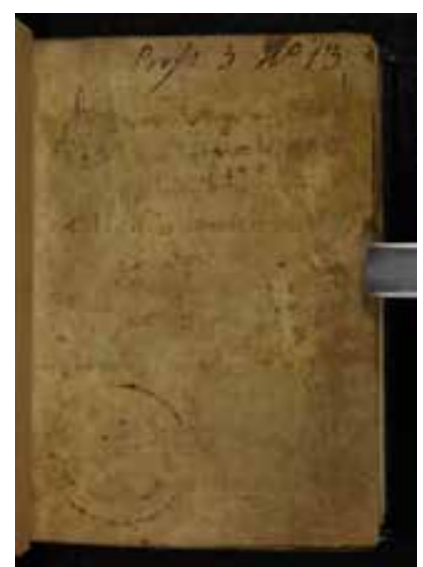

Fig. 77 Offsets of round badges on a blank folio at the beginning of the manuscript. London, British Library, Stowe Ms 17, fol. 1r (artwork in the public domain)

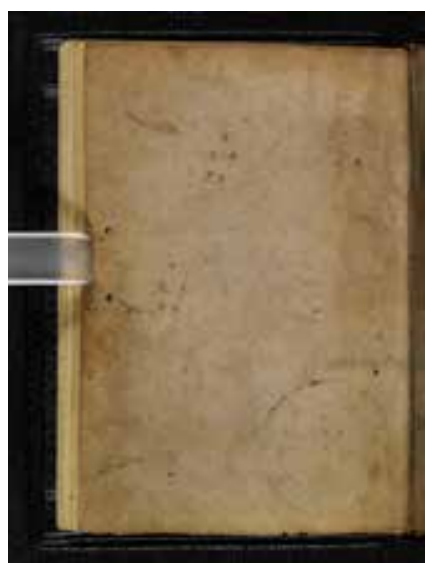

Fig. 78 Offsets of round badges on a blank folio at the beginning of the manuscript. London, British Library, Stowe Ms 17, fol. 1v (artwork in the public domain)

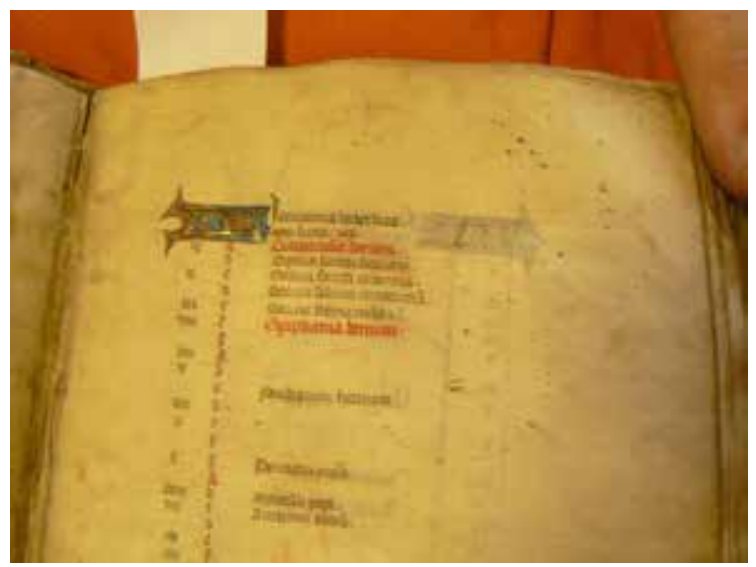

Fig. 79 January calendar page. Formerly London, Sotheby's, July 6 , 2010, lot 38 (unsold) (artwork in the public domain)

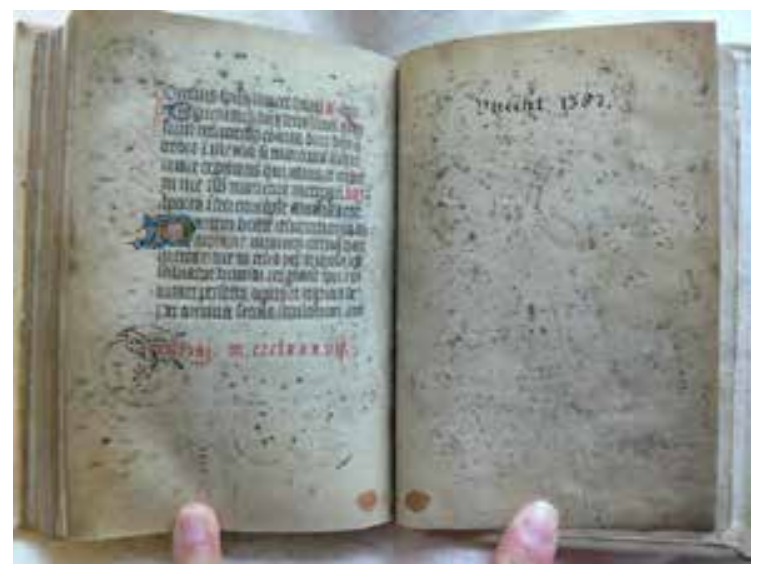

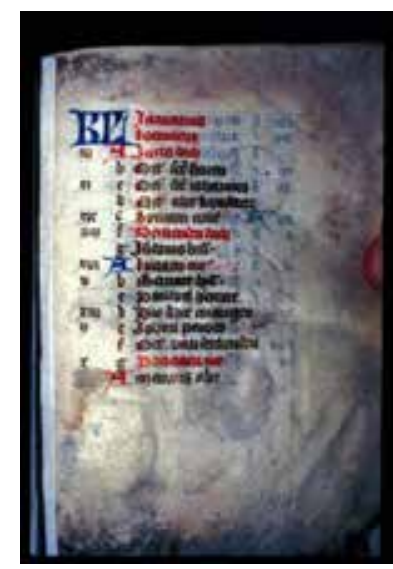

Fig. 80 January calendar page. New York, Morgan Library and Museum, Ms Wightman 2, fol. $1 r$ (artwork in the public domain; photo: James H. Marrow)

Fig. 81 Leaves at the end of the manuscript, with offsets of at least twenty-five round badges. Utrecht, Catharijneconvent, Ms BMH h160, fols. 78v-79r (artwork in the public domain; photo by the author)

32 While the examples above suggest that book owners inserted Eucharist badges into their books at specific places and in dialogue with specific texts, other book owners simply used the blank 
parchment available in the manuscript as a place to stow badges. Often the blank parchment occurs as flyleaves in the very beginning and very end of the book. Adding badges to these folios turns the manuscript into a commemorative shrine, where the covers of the book become like the lids of a box.

1. For example, a very early book of hours from Maastricht (London, British Library, Stowe Ms 17), made in the first quarter of the fourteenth century, has extraordinary imagery in its margins (no folio was left undecorated) (fig. 76). Perhaps the owner chose to sew at least six round badges to one of the flyleaves because the margins throughout the book were already filled with exuberant imagery (fol. 1r and v; figs. 77 and 78). Two of the offsets, apparently made by impressing the metallic body of Christ into the soft parchment, appear to be identical, and one wonders whether the badges were added simultaneously or on different Easters.

2. As the first text in a book of hours, the calendar often presented easily accessible space that readers filled in. Forensic evidence in both of the calendars with round offsets that I identified indicates that the badges overlapped the text and would have rendered it illegible. This suggests that the books' users treated the calendar as blank space. A French book of hours displayed at Sotheby's (July 6, 2010, lot 38; fig. 79) has a calendar with offsets from at least four round metal badges. ${ }^{31}$ The owner apparently attached these so that they covered parts of the calendar. Thus, the badges actually obscured the text and compromised the functioning of the calendar.

3. The owner of a Netherlandish book of hours similarly treated the calendar as a place to enshrine Eucharist badges (New York, Morgan Library and Museum, Ms Wightman 2, fol. 1r; fig. 80). These badges overlapped the text of the calendar, rendering it illegible and thereby giving the calendar a different function: to show that the book's owner had received the host at least three times.

4. A book of hours from Utrecht offers the most exuberantly used platform for the storage and display of round badges (Utrecht, Catharijneconvent, Ms BMH h160, fols. 78v-79r; fig. 81). There are offsets and sewing holes from at least twenty-five badges, all of them round and of varying sizes. Someone has written an incorrect date, 1387, in Roman numerals, which was retranscribed in Arabic numerals, but this is clearly a hundred years too early for this manuscript, to judge by its script and miniatures. Was someone trying to falsely age the manuscript, to lend it the gravitas of antiquity? That is unknowable. What is clear is that an owner or series of owners used the space at the end of the manuscript to make additions of various sorts. It is clear from the pattern of placement that the owner did not read, or at least did not value, the final text in the manuscript. Once the blank folio was filled up (with many of the badges overlapping!), she or he started filling the parchment on the facing folio. One gets the sense that this manuscript's owner was the type of person who rushed from church to church on Easter to observe as many Communions as possible, and picked up as many round tokens from the experience as he or she could. 


\section{Philip the Good's Badges}

33 Up till now I have been treating books with anonymous owners. As a counterpoint, considering the prayer books owned by Philip the Good allows one to see a single medieval votary's interactions with badges across two books. A tireless pilgrim, the duke collected badges from many saints' shrines and sewed them to the prayer book that had belonged to his grandfather, Philip the Bold, a book known as the Grandes Heures of Philip the Bold (now divided into Brussels, Koninklijke Bibliotheek Albert I, Ms 11035-37 and Cambridge, Fitzwilliam Museum, Ms 3-1954). ${ }^{32}$ Philip the Good visited especially those shrines lying within newly acquired territories. The grandson sewed in these badges, as Megan Foster convincingly argues, so that they would be juxtaposed with the relevant saint's suffrage. Less convincing, however, is her discussion concerning Philip the Good's famous "diptych codex" (Vienna, Österreichische Nationalbibliothek, Cod. 1800), a second prayer book into which the duke sewed badges. Foster notes that this manuscript contains needle holes on the front and back flyleaves, which formerly held eleven and twenty-two badges, respectively (fols. 32r and IIr; figs. 82 and 83). ${ }^{33}$ They were sewn neatly in rows, as if the process had started at the end of the brief manuscript (on fol. 32) and continued on the first flyleaf when that was full. Of the twenty-two offsets, all but five appear to be round; they were affixed according to shape, with four at the top of fol. 32r being rectilinear with an arched top. Following Dagmar Thoss, Foster suggests that a badge representing Saint Adrian at Geraardsbergen impressed one of the offsets with an arched top. ${ }^{34}$ However, not a single one of the round badges can be identified. Although I wholeheartedly agree with Foster that the thirty-three offsets "testify to the book's frequent devotional use by the duke," I question her assessment that "it seems highly likely that many of the badges would be Marian in theme." ${ }^{35}$ She correctly points out that the prayers in the manuscript are dedicated to the Virgin, Christ, the Holy Blood, and the Trinity, but I have a different interpretation of this state of affairs: I hypothesize that these badges originated in the duke's reputed daily attendance at Mass rather than his frequent stops at pilgrimage destinations. In short, I concur with Foster that Philip used his grandfather's manuscript, the Grandes Heures, to affix most of the tokens from the various saints' shrines (to match the badges with the suffrages to the same saint), but posit that he used the diptych codex mainly to collect Eucharist badges. Perhaps he took the small portable diptych-codex to Mass with him and associated this manuscript with celebrating the Mass, while he left his grandfather's much larger and more unwieldy prayer book at home. He filled the entire final folio of the diptych-codex with Eucharist badges, and when that was full, he began filling the first flyleaf.

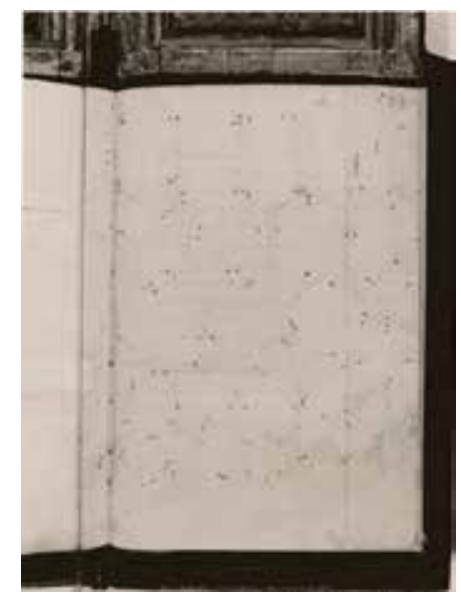

Fig. 82 Final folio of Philip the Good's "diptych codex," with numerous round offsets. Vienna, Österreichische Nationalbibliothek, Cod. 1800, fol. $32 r$ (artwork in the public domain)

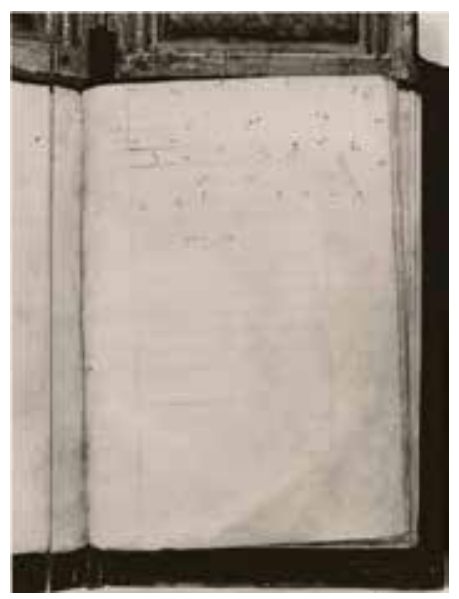

Fig. 83 Second front flyleaf of Philip the Good's "diptych codex," with round offsets filling the upper third of the page. Vienna, Österreichische Nationalbibliothek, Cod. 1800 , fol. IIr (artwork in the public domain) 


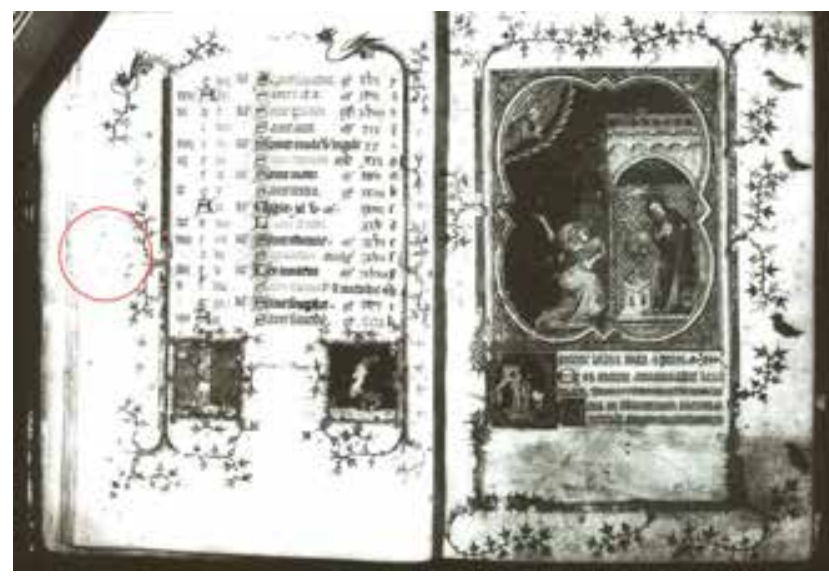

Fig. 84 The end of the calendar in the Grandes Heures of Philip the Bold, with a round offset at Christmas (indicated in red). Cambridge, Fitzwilliam Museum, Ms 3-1954, fols. 12v-13r (artwork in the public domain)

34 In light of my hypothesis that most round offsets were impressed by Eucharist badges not pilgrim badges, such an offset in the Cambridge volume of the Grandes Heures makes sense (Fitzwilliam Museum, Ms 3-1954, fol. 12v; fig. 84). ${ }^{36}$ This round offset appears on the final folio of the calendar. Specifically, it is juxtaposed with Christmas. Perhaps it commemorates the duke's having attended a particular Christmas Eve Mass. He may have put this Eucharist badge in the large prayer book, rather than in the diptych-codex with the other Eucharist badges, because the diptych-codex lacks a calendar, and the duke wanted to associate this particular wafer with Jesus's birthday. For the most part, however, he used the diptych-codex to commemorate his commitment to the Eucharist and his attendance at Mass, and primarily used the Grandes Heures, with its wide selection of suffrages, to affix badges memorializing saints and shrines.

\section{Conclusions}

35 I have argued here for a differentiation between pilgrims' badges and what I have named Eucharist badges. Whereas pilgrims' badges present an image of their referent, sometimes complete with gothic arches and shrinelike features, many Eucharist badges have the same size, shape, and iconography as their referents (Communion hosts): small, round, and bearing Christological imagery. They do not so much represent their referents as replicate them in a different (and more permanent) material. The iconography of the round, Christological badges is closely related to the iconography stamped onto Eucharist wafers. Whereas 75 percent of the religious badges in Kunera are not round, most of the badges sewn into manuscripts-as revealed by their offsetsare round. An explanation consistent with these findings is that Eucharist badges, not pilgrims' badges, made many offsets. I have proposed that believers could obtain ersatz hosts, made of a permanent material instead of bread, so that they could take home a piece of the holy, and then stitch it to their prayer books adjacent to texts and images relevant to seasonal Eucharistic devotion. Just as the host was itself already an approximation of the beloved body of Christ, the examples presented above suggest that votaries who could not get the host could at least approximate it.

36 Eucharist badges can be seen as the forerunners of early modern Communion tokens, which were enthusiastically used by Protestants, including Scottish Presbyterians and French and Dutch Calvinists and Lutherans. ${ }^{37}$ The Protestants' badges borrowed their predecessors' size, shape, and material, and to some degree, their iconography, as some even bear images of the Lamb of 
God. These later badges have a somewhat different function than that which I am proposing for the pre-1500 badges. As recent scholars such as Raymond Mentzer and Sabine Hiebsch have shown, Protestant ministers issued badges to the faithful who had attended classes in the weeks leading up to the Eucharist celebration. Only qualified parishioners were allowed to partake of Communion service, to ensure that the Eucharist would not be profaned by being ingested by the unworthy. ${ }^{38}$

37 In the late Middle Ages, placing Eucharist badges in manuscripts preserved the evidence of participation in Communion. It opened the possibility that the beholder could relive the experience through "ocular Communion" by revisiting the badges. How the badges were placed within books of hours not only illuminates how believers understood the Eucharist badges, but it also provides insight into how and when they read certain texts with which they wanted to associate the Eucharist. This is in tune with the badges' commemorative effect: they needed to be associated with what they recalled.

38 Believers' use of the book of hours was probably much more seasonally changeable than scholars have been accustomed to considering it. Votaries observed rituals in the liturgical year, which is one of the reasons that books of hours always begin with a calendar. I propose that the Hours of the Cross and the Hours of the Passion were primarily read during Passion week, the Penitential Psalms and Litany of the Saints during Lent. Both of these periods culminated in Easter, when Christian laypeople would normally consume their annual Eucharist. But in fact a large number of the prayers are all organized around Communion. Ersatz hosts indicate that the host is taken at Easter but then commemorated throughout the year. Perhaps at times other than at Easter Christians had only indirect contact with the host, by looking at it in a monstrance, seeing it in a Corpus Christi procession, contemplating it in a microarchitectural tower. All of these were about aggrandizing the host so that it was visible to many at once and from a considerable distance. Having a metallic host souvenir was one way to maintain the intimate scale of the original.

39 At stake in my argument is the question not only of how late medieval people thought of the Eucharist but of how they thought of their books: in part as repositories for collected objects that were imbued with the holy. Eucharist souvenirs were ritual mementos that believers could take home to create a sustained physical encounter with the Savior. In fact, the book became a shrine when it secreted away and protected a host. Based on the archeological and codicological evidence given here, I propose that the roundels often affixed to books of hours commemorated the experience of taking the Eucharist and made a fleeting experience tangible and permanent. Their tangibility would also have made the pages to which they were affixed immediately identifiable, even when the book was closed. They served as finding aids, as they would have caused the book to fall open at key pages.

40 Adding badges must have made votaries feel like participants in the construction of their books. It involved them in a bookish ritual, which both demanded and reinforced their commitment to the Corpus Christi. In 1896 the Sperry and Hutchinson Company would use a similar psychology when they issued S\&H Green Stamps. Shoppers collected them at gas stations and grocery stores and then pasted them into booklets. Filled booklets could be redeemed for prizes. Both Green Stamps and Eucharist badges engender cultural techniques that result in redemption. Part of 
Green Stamps' success as a marketing loyalty scheme was that collecting the stamps demanded a level of physical involvement. The satisfaction of affixing them to the pages was (I remember as a kid) quite high, and the event was often a social one. One wonders, too, whether late medieval votaries treated their collected badges as proof of prayer-tangible proof that they had recited the prayers in the book and were candidates for redemption. And, of course, sewing badges into manuscript was social at least in so far as the process spread by social networks as the thing to do with one's badges.

41 Badges sewn into books had the ability to reshape the book, not just in terms of leaving an offset but in helping to shape and reflect the prayers that surrounded them. Many believers, even literate ones, did not learn how to write, for reading and writing were considered separate processes, and writing was not widely taught. Many lay believers would have owned a book of hours but would not have been capable of writing one, most could barely write their names. Instead of writing textual labels for their Eucharist badges, as one might do for a relic, believers simply placed them in their books of hours, often next to the text that was most relevant to the host. They let the books thereby serve as a label, as a storage system, as a collection point, and as a shrine for their Eucharist badges.

\section{Acknowledgements}

I cordially thank Aden Kumler, who invited me to present this material to her graduate students at the University of Chicago and for providing me with many valuable references. I also thank Prof. Lucia Travaini for providing me with a copy of her essay before publication. I also extend my gratitude to Hanneke van Asperen, who provided the numerical data from the Kunera database from which I generated the graphs.

Kathryn M. Rudy is Senior Lecturer in Art History at the University of St Andrews and is a former Curator of Illuminated Manuscripts at the Royal Library of the Netherlands. She is the author, most recently, of Postcards on Parchment (Yale University Press, 2015), is currently finishing a book about relationships between images and indulgences in the century before the Protestant Reformation and is well underway with a new book about how medieval people physically handled their manuscripts. kmr7@st-andrews.ac.uk

\section{List of Illustrations}

Fig. 1 Breakdown by type of the 18,971 items in the Kunera database.

Fig. 2 Folio from a book of hours with illumination attributed to the Master of Catherine of Cleves. Baltimore, Walters Art Museum, Ms W 782, fol. 113r (artwork in the public domain)

Fig. 3 Flyleaf with offsets of round metallic objects that have since been removed. The Hague, Koninklijke Bibliotheek, Ms 74 G 5, fol. Ir. (artwork in the public domain)

Fig. 4 Selection of pilgrims' badges from known shrines, culled from the Kunera database 
Fig. 5 Screen shot of the Kunera database showing a selection of the 331 badges with Passion and Resurrection subjects, which are not connected to a particular pilgrimage shrine.

Fig. 6 Screen shot of the Kunera database showing a selection of the badges with the IHS monogram.

Fig. 7 Screen shot of the Kunera database showing a selection of the badges with the face of Christ.

Fig. 8 Screen shot of the Kunera database showing a selection of the badges showing a pelican piercing its breast.

Fig. 9 Screen shot of the Kunera database showing a selection of the badges with the Lamb of God.

Fig. 10 Christological badges with the Lamb of God, what I am terming here Eucharist badges, culled from the Kunera database

Fig. 11 Screen shot of the Kunera database showing a selection of cruciform objects.

Fig. 12 Four round Christological badges with hangers from the Kunera database.

Fig. 13 Badge of the three miraculous hosts of Andechs (Kunera no. 06534)

Fig. 14 Badge of the three miraculous hosts of Wilsnack (Kunera no. 00135)

Fig. 15 Badge of the three miraculous hosts of Wilsnack, showing three hosts bearing Passion imagery (the Crucifixion, Resurrection, and Flagellation) (Kunera no. 13628)

Fig. 16 Badge of the host desecration at Blomberg, showing a woman throwing forty-five hosts into a well (Kunera no. 04674)

Fig. 17 Chart comparing religious and profane badges in the Kunera database.

Fig. 18 Chart breaking down the religious badges by shape. Of surviving religious badges 14 percent are disklike (bracteate) in form, while 11 percent incorporate open latticework surrounded by a round frame.

Fig. 19 Eucharist wafer iron, ca. 1390-1410. Stockholm, Statens Historiska Museum (Museum of National Antiquities) (artwork in the public domain)

Fig. 20 Incipit of prayers to the Sacrament, with an offset of a round badge on the left-hand folio. The Hague, Koninklijke Bibliotheek, Ms 131 H 10, fols. 202v-203r (artwork in the public domain; photo by the author) 
Fig. 21 Detail of fig. 20 (artwork in the public domain; photo by the author)

Fig. 22 Lower margin from of a book of hours just before prayers to the Sacrament, Bruges, Stadsbibliotheek, Ms 674, fol. 115r (artwork in the public domain; photo by the author)

Fig. 23 Opening of a book of hours, with the incipit for prayers to the Sacrament. Bruges, Stadsbibliotheek, Ms 674, fol. 116r (artwork in the public domain; photo by the author)

Fig. 24 Incipit of a prayer to the Sacrament, with a round offset. Brussels, Koninklijke Bibliotheek Albert I, Ms IV 1000, fol. 158r (artwork in the public domain)

Fig. 25 Crucifixion miniature to preface the Hours of the Cross, with several offsets of round badges in the margin. Brussels, Koninklijke Bibliotheek, Ms 10541, fol. 10v. (artwork in the public domain)

Fig. 26 Detail of last page of the Hours of the Passion. Cambridge, Fitzwilliam Museum, Ms 135, fol. $32 \mathrm{v}$ (artwork in the public domain)

Fig. 27 Text page from the Hours of the Passion. Cambridge, Fitzwilliam Museum, Ms 135, fol. $23 r$ (artwork in the public domain)

Fig. 28 Full-page Crucifixion, inserted before the Long Hours of the Cross, with round offsets. The Hague, Koninklijke Bibliotheek, Ms BPH 137, fols. 13v-14r (artwork in the public domain; photo by the author)

Fig. 29 Detail of the top left corner of the Crucifixion miniature (fig. 28: fol. 13v), photographed with backlighting to reveal needle holes (artwork in the public domain; photo by the author)

Fig. 30 Thread from sewing-in the round badge on the folio with the rubric announcing the Short Hours of the Cross. The Hague, Koninklijke Bibliotheek, Ms BPH 137, fol. 100r (artwork in the public domain; photo: Byvanck Genootschap)

Fig. 31 Incipit of the Short Hours of the Cross, with an offset from a round badge. The Hague, Koninklijke Bibliotheek, Ms BPH 137, fols. 100v-101r (artwork in the public domain; photo by the author)

Fig. 32 Lamb of God with inscription (parchment painting in its current manuscript context, trimmed into a roundel) before the Hours of the Cross. Olim Delft, Prinsenhof, fols. 52v-53r (artwork in the public domain)

Fig. 33 Incipit of the Hours of the Cross, with round offsets. The Hague, Meermanno Museum, Ms 10 F 15, fol. 8r (artwork in the public domain)

Fig. 34 Crucifixion prefacing the Hours of the Cross, with a round offset. The Hague, Koninklijke Bibliotheek, Ms 135 E 22, fol. 103v (artwork in the public domain) 
Fig. 35 Detail of needle holes. The Hague, Koninklijke Bibliotheek, Ms 135 E 22, fol. 103r (artwork in the public domain; photo by the author)

Fig. 36 Folio from the Hours of the Cross, with the Lamb of God painted in the lower margin. The Hague, Koninklijke Bibliotheek, Ms 135 E 22, fol. 117r (artwork in the public domain)

Fig. 37 Incipit of the Short Hours of the Cross, with a Lamb of God roundel painted in the margin. Olim Nijmegen, Jezuitenbibliotheek Berchmanianum (now Leuven, Maurits Sabbebibliotheek), Ms 5000 A 30, fol. 1r (artwork in the public domain; photo: Byvanck Genootschap)

Fig. 38 Incipit of the Short Hours of the Cross, with a Lamb of God roundel painted in the margin. Oxford, Bodleian Library, Douce Ms 248, fol. 66r (artwork in the public domain)

Fig. 39 Incipit of the Hours of the Cross, with a Lamb of God roundel painted in the margin. Leiden Universiteitsbibliotheek, Ms Ltk 1985, fol. 82r (artwork in the public domain)

Fig. 40 Incipit of the Hours of the Virgin, with a full-page miniature depicting the Annunciation, and the offsets of two round badges at the lower margin. Utrecht, Catharijneconvent, Ms BMH h63, fols. 16v-17r (artwork in the public domain; photo: Byvanck Genootschap)

Fig. 41 Leaf ruled for an image (never filled in) with at least eighteen more round offsets on a blank leaf prefacing the Hours of the Virgin. The Hague, Koninklijke Bibliotheek, Ms 74 G 5, fols. $13 \mathrm{v}-14 \mathrm{r}$ (artwork in the public domain)

Fig. 42 Blank opening before the Hours of the Virgin. The Hague, Koninklijke Bibliotheek, Ms 74 $\mathrm{G} 35$, fols. $13 \mathrm{v}-14 \mathrm{r}$ (artwork in the public domain; photo by the author)

Fig. 43 Incipit of the Hours of the Virgin. The Hague, Koninklijke Bibliotheek, Ms 74 G 35, fols. $14 \mathrm{v}-15 \mathrm{r}$ (artwork in the public domain)

Fig. 44 Hours of the Virgin, with the offset of a round badge at the upper corner. The Hague, Meermanno Museum, Ms 10 F 2, fols. 14v-15r (artwork in the public domain; photo by the author)

Fig. 45 Offset of a round badge (detail of fig. 44: fol. 15r) (photo by the author)

Fig. 46 Folio formerly prefacing the Hours of the Virgin (before the full-page Annunciation was added), with the offset of a round badge at the upper corner. The Hague, Meermanno Museum, Ms 10 F 2, fol. 13v (artwork in the public domain; photo by the author)

Fig. 47 Prime within the Hours of the Virgin. Bruges, Stadsbibliotheek, Ms 329, fol. 62r (artwork in the public domain; photo: Hanneke van Asperen)

Fig. 48 Drawing of the face of Christ. Ghent, Universiteitsbibliotheek, Ms 1353, fol. 114v (artwork 
in the public domain; photo: the author)

Fig. 49 A painting depicting the Trinity (added to this prayer book of ca. 1394 in the fifteenth century). Ghent, Universiteitsbibliotheek, Ms 1353, fols. 2v-3r. (artwork in the public domain; photo by the author)

Fig. 50 A painting depicting the Virgin and Child (added to this prayer book of ca. 1394 in the fifteenth century). Ghent, Universiteitsbibliotheek, Ms 1353, fols. 116v-117r (artwork in the public domain; photo by the author)

Fig. 51 Detail of fig. 50 (fol. 116v) showing needle holes (photo by the author)

Fig. 52 Needle holes shown in fig. 51, seen with backlighting (photo by the author)

Fig. 53 Incipit of the Hours of the Virgin, with a Lamb of God roundel in the margin. Tilburg, Universiteitsbibliotheek, Haaren 4, fol. 15r (artwork in the public domain; photo: Byvanck Genootschap)

Fig. 54 The end of the Seven Penitential Psalms and Litany of the Saints, with offsets from at least seven round badges. The Hague, Koninklijke Bibliotheek, Ms 133 M 23, fols. 129v-130r (artwork in the public domain)

Fig. 55 Incipit of the Seven Penitential Psalms and Litany of the Saints. The Hague, Koninklijke Bibliotheek, Ms 133 M 23, fols. 105v-106r (artwork in the public domain)

Fig. 56 Lamb of God roundel illusionistically painted in the margin on a page at the end of the "ut" and "per" statements (the end of the Litany of the Saints). The Hague, Koninklijke Bibliotheek, Ms 135 F 2, fol. 136r (artwork in the public domain)

Fig. 57 Lamb of God roundel painted at the lower margin of the incipit of the Seven Penitential Psalms. Utrecht, Catharijneconvent, Ms ABM h58, fol. 121r (artwork in the public domain; photo: Byvanck Genootschap)

Fig. 58 Lamb of God roundel painted at the lower margin of the incipit of the Seven Penitential Psalms. Retz, Stadtarchiv, Inv. no. 65/23 (artwork in the public domain)

Fig. 59 Incipit of the Seven Penitential Psalms. The Hague, Koninklijke Bibliotheek, Ms 78 J 7, fol. 73r (artwork in the public domain)

Fig. 60 Reverse of Last Judgment print, inserted to preface the Seven Penitential Psalms, with needle holes from round badges formerly attached to the print. Brussels, Koninklijke Bibliotheek, Ms IV 142, fol. 101r (artwork in the public domain; photo by the author)

Fig. 61 Last Judgment print, inserted to preface the Seven Penitential Psalms, with offsets from round badges formerly sewn to the back of the print. Brussels, Koninklijke Bibliotheek, Ms. IV 
142, fols. 101v-102r (artwork in the public domain)

Fig. 62 Reverse of Annunciation print, inserted to preface the Hours of the Virgin, with offset of a round badge formerly attached to the blank back of the print. Brussels, Koninklijke Bibliotheek, Ms IV 142, fol. 14r (artwork in the public domain; photo by the author)

Fig. 63 Annunciation print, inserted to preface the Hours of the Virgin. Brussels, Koninklijke Bibliotheek, Ms IV 142, fol. 14v (artwork in the public domain; photo by the author)

Fig. 64 Final flyleaf, with at least eight round offsets. Liège, University Library, Ms Wittert 32 (artwork in the public domain; photo by the author)

Fig. 65 Folio within the Penitential Psalms, with a round offset (?) at upper margin. Liège, University Library, Ms Wittert 32, fol. 144r (artwork in the public domain; photo: Byvanck Genootschap)

Fig. 66 Folio with the suffrage to Saint Peter, with a round offset at the side margin. Liège, University Library, Ms Wittert 32, fol. 116v (artwork in the public domain; photo by the author)

Fig. 67 Incipit of the Hours of the Virgin, with offsets of round badges on the facing folio. Utrecht Universiteitsbibliotheek, Ms 15 C 9, fols. 20v-21r (artwork in the public domain; photo by the author)

Fig. 68 Incipit of the Hours of the Cross, with a single offset of a round badges at the lower corner. Utrecht, Universiteitsbibliotheek, Ms 15 C 9, fol. 95r (artwork in the public domain; photo by the author)

Fig. 69 The blank backs of two grisaille miniatures, with offsets of round badges on the left-hand folio. Antwerp, Plantin Museum, Ms 14.19, fols. 171v-172r (artwork in the public domain; photo by the author)

Fig. 70 Grisaille miniature of Saint Peter, with offsets of round badges in the margin. Antwerp, Plantin Museum, Ms 14.19, fol. 168r (artwork in the public domain; photo by the author)

Fig. 71 Grisaille miniature of Saint John the Baptist, with offsets of round badges on the back. Antwerp, Plantin Museum, Ms 14.19, fol. 171r (artwork in the public domain; photo by the author)

Fig. 72 Grisaille miniature of Saint John the Baptist, with offsets of round badges on the back. Antwerp, Plantin Museum, Ms 14.19, fol. 171v (artwork in the public domain; photo by the author)

Fig. 73 Hours of the Passion and of His Dear Mother Mary. Nijmegen, Universiteitsbibliotheek, Ms 320, fol. 14r (artwork in the public domain; photo: Byvanck Genootschap)

Fig. 74 Sext of the Hours of the Passion and of His Dear Mother Mary. Nijmegen, Universiteitsbibliotheek, Ms 320, fol. 18v (artwork in the public domain; photo: Byvanck Genootschap) 
Fig. 75 Prime of the Hours of the Virgin. Nijmegen, Universiteitsbibliotheek, Ms 320, fol. 44v (artwork in the public domain; photo: Byvanck Genootschap)

Fig. 76 Folio with painted borders typical of this manuscript. London, British Library, Stowe Ms 17 , fol. $35 \mathrm{v}$ (artwork in the public domain)

Fig. 77 Offsets of round badges on a blank folio at the beginning of the manuscript. London, British Library, Stowe Ms 17, fol. 1r (artwork in the public domain)

Fig. 78 Offsets of round badges on a blank folio at the beginning of the manuscript. London, British Library, Stowe Ms 17, fol. 1v (artwork in the public domain)

Fig. 79 January calendar page. Formerly London, Sotheby's, July 6, 2010, lot 38 (unsold) (artwork in the public domain)

Fig. 80 January calendar page. New York, Morgan Library and Museum, Ms Wightman 2, fol. 1r (artwork in the public domain; photo: James H. Marrow)

Fig. 81 Leaves at the end of the manuscript, with offsets of at least twenty-five round badges. Utrecht, Catharijneconvent, Ms BMH h160, fols. 78v-79r (artwork in the public domain; photo by the author)

Fig. 82 Final folio of Philip the Good's "diptych codex," with numerous round offsets. Vienna, Österreichische Nationalbibliothek, Cod. 1800, fol. 32r (artwork in the public domain)

Fig. 83 Second front flyleaf of Philip the Good's "diptych codex," with round offsets filling the upper third of the page. Vienna, Österreichische Nationalbibliothek, Cod. 1800, fol. IIr (artwork in the public domain)

Fig. 84 The end of the calendar in the Grandes Heuresof Philip the Bold, with a round offset at Christmas (indicated in red). Cambridge, Fitzwilliam Museum, Ms 3-1954, fols. 12v-13r (artwork in the public domain)

${ }^{1}$ Miri Rubin, Corpus Christi: The Eucharist in Late Medieval Culture (Cambridge and New York: Cambridge University Press, 1991). See also: Achim Timmermann, "A View of the Eucharist on the Eve of the Protestant Reformation," in A Companion to the Eucharist in the Reformation, ed. Lee Palmer Wandel (Leiden: Brill, 2014), 365-98; Achim Timmermann, Real Presence: Sacrament Houses and the Body of Christ, c. 1270-1600, Architectura Medii Aevi (Turnhout: Brepols, 2009); Charles Zika, "Hosts, Processions and Pilgrimages: Controlling the Sacred in Fifteenth-Century Germany," Past and Present 118 (1988): 25-64 (http://dx.doi.org/10.1093/past/118.1.25); Gary Macy, The Banquet's Wisdom: A Short History of the Theologies of the Lord's Supper (New York: Paulist Press, 1992); Gary Macy, The Theologies of the Eucharist in the Early Scholastic Period: A 
Study of the Salvific Function of the Sacrament According to the Theologians, c. 1080-c.1220 (Oxford: Clarendon Press, 1984); Peter Browe, Die Eucharistischen Wunder des Mittelalters, Breslauer Studien zur Historischen Theologie N. F. 4 (Breslau: Verlag Müller \& Seiffert, 1938). See also the chapter "ocular Communion" in Suzannah Biernoff, Sight and Embodiment in the Middle Ages, The New Middle Ages (Houndmills, U.K. and New York: Palgrave Macmillan, 2002) (http:// dx.doi.org/10.1057/9780230508354) with further references. I am also indebted to the excellent articles in A Companion to the Eucharist in the Middle Ages, ed. Ian Christopher Levy, Gary Macy, and Kristen Van Ausdall, Brill's Companions to the Christian Tradition (Leiden and Boston: Brill, 2011), especially those by Edward Foley, Gary Macy, Ian Christopher Levy, Miri Rubin, Gerhard Lutz, Stephen Edmund Lahey, and Kristen Van Ausdall.

${ }^{2}$ I am wary of the term "virtual pilgrimage," which has been applied recently to too many various forms of devotion that have only a tangential relationship to pilgrimage, virtual or corporeal.

I am therefore not calling the "journey" to the altar to see the Eucharist a "virtual pilgrimage." Many late medieval devotional practices had a physical component, but this does not make them "pilgrimages." See my review of Sarah Blick and Laura D. Gelfand, eds., Push Me, Pull You: Imaginative, Emotional, Physical, and Spatial Interaction in Late Medieval and Renaissance Art (Leiden: Brill Academic Publishers 2011), online at http://www.sehepunkte.de (June 2012).

${ }^{3}$ I first made this suggestion in: "Kissing Images, Unfurling Rolls, Measuring Wounds, Sewing Badges and Carrying Talismans: Considering Some Harley Manuscripts through the Physical Rituals They Reveal," in Proceedings from the Harley Conference, British Library, 29-30 June 2009, in $e B L J, 2011$, article 5 (http://www.bl.uk/eblj/2011articles/article5.html). Aden Kumler comes to a similar conclusion - that round badges with images of the Lamb of God stamped on them-betokened the Eucharist, in Aden Kumler, "The Multiplication of the Species: Eucharistic Morphology in the Middle Ages," Res 59/60 (2011): 179-91. I thank Dr. Kumler for providing me with a copy of her article before its publication.

${ }^{4}$ Kathryn Rudy, Postcards on Parchment: The Social Lives of Medieval Books (New Haven and London: Yale University Press, 2015), chapt. 10.

${ }^{5}$ Arthur Forgeais, Collection de Plombs Historiés Trouvés dans La Seine et Recueillis par Arthur Forgeais, 5 vols. (Paris: Chez l'auteur et chez Aubry, 1862-66).

${ }^{6}$ Kurt Köster, “Gutenbergs Aachener Heiltumsspiegel," in Das Werck der Bücher: Von der Wirksamkeit des Buches in Vergangenheit und Gegenwart, ed. Fritz Hodeige (Freiburg: Verlag Rombach, 1956), 284-301; Kurt Köster, "Religiöse Medaillen und Wallfahrts-Devotionalien in der Flämischen Buchmalerei des 15. und frühen 16. Jhs. zur Kenntnis gemalter und wirklicher Kollektionen in Spät-Mittelalterlichen Gebetbüchern," in Buch und Welt: Festschrift für Gustav Hofmann, zum 65. Geburtstag dargebracht, ed. Hans Striedl and Joachim Wieder (Wiesbaden: O. Harrassowitz, 1965), 459-504; Kurt Köster, Pilgerzeichen und Pilgermuscheln von mittelalterlichen Santiagostrassen: Saint-Léonard, Rocamadour, Saint-Gilles, Santiago de Compostela, Ausgrabungen in Schleswig (Neumünster: K. Wachholtz, 1983); Kurt Köster, "Gemalte Kollektionen von Pilgerzeichen und Religiösen Medaillen in Flämischen Gebet- und Stundenbüchern des 15. und frühen 16. Jahrhunderts. Neue Funde in Handschriften der Gent-Brügger Schule," in Liber Amicorum Herman Liebaers, ed. F. L. J. Vanwijngaerden, Jean-Marie Duvosque, and Josette Mélard (Brussels: Pour les Amis de la Bibliotèque royale Albert Ier par le Crédit Communal de Belgique, 1984), 486-535; Kurt Köster, "Mittelalterliche Pilgerzeichen," in Wallfahrt kennt keine Grenzen: Themen zu einer Ausstellung des Bayerischen Nationalmuseums und des Adalbert Stifter Vereins, München, ed. Lenz Kriss-Rettenbeck and Gerda Möhler (Munich: Schnell \& Steiner, 1984), 203-23, and 
other articles on similar themes too numerous to list.

${ }^{7}$ For example, A. M. Koldeweij, Geloof en Geluk: Sieraad en Devotie in Middeleeuws Vlaanderen (Arnhem: Terra, 2006).

${ }^{8}$ Isabel von Bredow-Klaus, Heilsrahmen: Spirituelle Wallfahrt und Augentrug in der Flämischen Buchmalerei des Spätmittelalters und der frühen Neuzeit (Munich: Herbert Utz, 2009); Megan Foster-Campbell, "Pilgrimage through the Pages: Pilgrims' Badges in Late Medieval Devotional Manuscripts," in Push Me, Pull You: Imaginative and Emotional Interaction in Late Medieval and Renaissance Art, ed. Sarah Blick and Laura Deborah Gelfand, Studies in Medieval and Reformation Traditions (Leiden: Brill, 2011), 227-74.

${ }^{9}$ Kurt Köster, "Kollektionen Metallener Wallfahrts-Devotionalien und kleiner Andachtsbilder, eingenäht in spätmittelalterliche Gebetbuch-Handschriften," in Erlesenes aus der Welt des Buches, vol. 1 of Das Buch und sein Haus: Gerhard Liebers gewidmet zur Vollendung des 65. Lebensjahrs am 23. Mai 1979, eds. Bertram Haller and Rolf Fuhlrott (Wiesbaden: Reichert, 1979), 77-130.

${ }^{10}$ For a physical description, images, and further bibliography for Baltimore, Walters Art Museum, Ms W. 782, see http://thedigitalwalters.org/Data/

WaltersManuscripts/html/W782/description.html

${ }^{11}$ In a similar way, pages - including carpet pages-painted with representations of textiles may refer to the practice of sewing precious silk textiles into manuscripts. See Christine Sciacca, "Raising the Curtain on the Use of Textiles in Manuscripts," in Weaving, Veiling, and Dressing: Textiles and Their Metaphors in the Late Middle Ages, ed. Kathryn M. Rudy and Barbara Baert, Medieval Church Studies 12 (Turnhout: Brepols, 2007), 161-90. http://dx.doi.org/10.1484/M.

MCS-EB.3.1875

${ }^{12}$ Kathryn M. Rudy, "Sewing as Authority in the Middle Ages," Zeitschrift für Medien- und Kulturforschung (2015): 117-31.

${ }^{13}$ Hanneke van Asperen, "Pelgrimstekens op Perkament: Originele en Nageschilderde Bedevaartssouvenirs in Religieuze Boeken (ca 1450-ca 1530)," PhD diss. (Radboud Universiteit Nijmegen, 2009).

${ }^{14}$ There is a large bibliography on Wilsnack. See Caroline Walker Bynum, Wonderful Blood: Theology and Practice in Late Medieval Northern Germany and Beyond, Middle Ages Series (Philadelphia: University of Pennsylvania Press, 2007); and Caroline Walker Bynum, "Bleeding Hosts and Their Contact Relics in Late Medieval Northern Germany," Medieval History Journal 7, no. 2 (2004): 227-41 (http://dx.doi.org/10.1177/097194580400700204), with further references.

${ }^{15}$ Vincent Ambrosiani, "Le Monogramme IHS sur les Hosties," Revue de l'Art Chrétien, n.s. 3 (1885): 225-29, explains the meaning of the letters IHS and speculates on the origin of the monogram.

${ }^{16}$ William J. Courtenay, "Token Coinage and the Administration of Poor Relief During the Late Middle Ages," Journal of Interdisciplinary History 3, no. 2 (1972): 275-95. http://dx.doi. org/10.2307/202331

${ }^{17}$ Ibid, p. 277.

${ }^{18}$ Carina Brumme, "Fromme Devotionalien und volkstümliche Festrequisiten—zur Verwendung der spätmittelalterlichen Miniaturkronen," in Wallfahrer aus dem Osten: Mittelalterliche Pilgerzeichen zwischen Ostsee, Donau und Seine; Beiträge der Tagung "Perspektiven der europäischen Pilgerzeichenforschung," 21. bis 24. April 2010 in Prag, ed. Hartmut Kühne, Lothar Lambacher, and Jan Hrdina, Europäische Wallfahrtsstudien 10 (2013): 461-74.

${ }^{19}$ See Kumler, “The Multiplication of the Species" 184; and Aden Kumler, “The 'Genealogy of Jean 
le Blank': Accounting for the Materiality of the Medieval Eucharist," in The Matter of Art: Materials, Practices, Cultural Logics, c. 1250-1750, ed. Christy Anderson, Anne Dunlop, and Pamela H. Smith (Manchester: Manchester University Press, 2015), 119-40 (see n. 14 for further references). ${ }^{20}$ Rubin, Corpus Christi, 39; see also the important study: Lucia Travaini, "Coins as Bread, Bread as Coins," Numismatic Chronicle 173 (2013): 187-200.

${ }^{21}$ Rubin, Corpus Christi, 43.

${ }^{22}$ Ibid., 63, citing The Sermons of Thomas Brinton, 212-17, no. 48.

${ }^{23}$ Caroline Walker Bynum, Christian Materiality: An Essay on Religion in Late Medieval Europe (Cambridge, Mass.: Zone Books, distributed by the MIT Press, 2011).

${ }^{24}$ In Postcards on Parchment I argue that ersatz hosts made of parchment and paper were also designed to be affixed to manuscripts. These flat objects likewise appear at the Hours of the Cross, the Penitential Psalms, and at texts with sacramental themes.

${ }^{25}$ For example, Roger S. Wieck, Time Sanctified: The Book of Hours in Medieval Art and Life (New York: G. Braziller, in association with the Walters Art Gallery, Baltimore, 1988), 89, writes, "In many manuscripts, the Hours of the Cross and the Hours of the Holy Spirit follow one right after the other, together forming a kind of unit. Their placement within a Book of Hours is not fixed but they often come immediately after the Hours of the Virgin, and it seems clear that this arrangement encouraged, time permitting, the reader to pray these two Hours right after finishing those devoted to Mary." However, the evidence of cumulative wear, visible in many books of hours, does not support this hypothesis. See Kathryn M. Rudy, "Dirty Books: Quantifying Patterns of Use in Medieval Manuscripts Using a Densitometer," Journal of Historians of Netherlandish Art 2, no. 1 (2010). http://dx.doi.org/10.5092/jhna.2010.2.1.1

${ }^{26}$ See Nancy Vine Durling, "Birthmarks and Bookmarks: The Example of a Thirteenth-Century French Anthology," Exemplaria 16, no. 1 (2004): 81-82 (http://dx.doi.org/10.1179/ exm.2004.16.1.73), for a Middle French poem in which Love "with her needles pricks me and causes me great pain." For a fuller discussion of this image, see Rudy, Postcards on Parchment, 233-34.

${ }^{77}$ Around 2006 the manuscripts in the Jezuitenbibliotheek Berchmanianum Nijmegen were moved to the Faculty of Theology at the University of Leuven (http://theo.kuleuven.be/gbib/erfgoed/erfgoed).

${ }^{28}$ For Bruges, Stadsbibliotheek, Ms 329, see A. M. Koldeweij, Geloof en Geluk: Sieraad en Devotie in Middeleeuws Vlaanderen (Arnhem: Terra, 2006).

${ }^{29}$ Some texts in this manuscript (such as the Hours of the Virgin and the Penitential Psalms) show more signs of wear than other texts. Because the edges had been trimmed, I was not able to quantify the use with the densitometer.

${ }^{30}$ For images, a description and further bibliography, see http://www.handschriftencensus. de/10469.

${ }^{31}$ The manuscript was apparently not sold.

${ }^{32}$ Patrick M. de Winter, "The Grandes Heures of Philip the Bold, Duke of Burgundy: The Copyist Jean L'Avenant and His Patrons at the French Court," Speculum 57, no. 4 (1982): 786-842 (http:// dx.doi.org/10.2307/2848764), first connects the two volumes; see also Patrick M. de Winter, $L a$ Bibliothèque de Philippe le Hardi, Duc de Bourgogne (1364-1404): Étude sur les Manuscrits é Peintures d'une Collection Princière à Lépoque du "Style Gothique International," Documents, Études et Rèpertoires / Institut de Recherche et d'Histoire des Textes (Paris: Centre national de le recherche scientifique, 1985). For the Cambridge volume, see Francis Wormald and Phyllis M. Giles, 
"Description of Fitzwilliam Museum Ms. 3-1954," Transactions of the Cambridge Bibliographical Society 4, no. 1 (1964): 1-28. Anne Hagopian van Buren, "Dreux Jehan and the Grandes Heures of Philip the Bold," in Als Ich Can: Liber Amicorum in Memory of Professor Dr. Maurits Smeyers, ed. Bert Cardon, et al., Corpus of Illuminated Manuscripts = Corpus Van Verluchte Handschriften (Leuven: Peeters, 2002), 1377-1414, provides an account of the manuscript's complicated stratigraphy.

${ }^{33}$ Megan H. Foster, "Pilgrimage through the Pages: Pilgrims' Badges in Late Medieval devotional Manuscripts” (PhD diss., University of Illinois at Urbana-Champaign, 2011), 115.

${ }^{34}$ Ibid., p. 125; Dagmar Thoss and Otto Mazal, Das Buchaltärchen Herzog Philipps des Guten von Burgund: Codex 1800 der Österreichischen Nationalbibliothek in Wien = Le Livre-Autel de Philippe Le Bon, Duc de Bourgogne: Codex 1800 de la Bibliothèque Nationale Autrichienne de Vienne (Lucerne: Faksimile-Verlag, 1991), 128.

${ }^{35}$ Foster, "Pilgrimage through the Pages," 127.

${ }^{36}$ Ibid., fig. 11.

${ }^{37}$ See Thomas Burns and Patrick Cochran, The Communion Token (n.p.: Galata, 2011); O. D. Cresswell, Cresswell's Comprehensive Directory of World Communion Tokens (Ottawa: Nadin-Davis, 1985); H. A. Whitelaw, Communion Tokens: With Illustrated and Descriptive Catalogue of Those of Dumfriesshire (Dumfries: Council of the Dumfries and Galloway Natural History and Antiquarian Society, Dumfries and Maxwelltown Ewart Public Library, 1911); Robert Dick, Scottish Communion Tokens: Other Than Those of the Established Church (Edinburgh: A. Elliot, 1902). ${ }^{38}$ Raymond A. Mentzer, "The Reformed Churches of France and the Visual Arts," in Seeing Beyond the Word: Visual Arts and the Calvinist Tradition, ed. Paul Corby Finney (Grand Rapids, Mich.: Eerdmans, 1999), esp. 220-28; Sabine Hiebsch, “Tastbaar Geloof: Avondmaalsloodjes in Nederlandse Lutherse Gemeenten," in Van Pakhuis tot Preekhuis: 425 Jaar Lutherse Gemeente in Amsterdam (1588-2013), ed. Sabine Hiebsch and Martin L. van Wijngaarden (Zoetermeer: Boekencentrum, 2013), 87-108.

\section{Bibliography}

Ambrosiani, Vincent. "Le Monogramme IHS Sur Les Hosties.” Revue de l'Art Chrétien, n.s. 3 (1885): 225-29.

Asperen, Hanneke van. "Pelgrimstekens op Perkament: Originele en Nageschilderde Bedevaartssouvenirs in Religieuze Boeken (ca 1450-ca 1530).” PhD diss., Radboud Universiteit Nijmegen, 2009.

Biernoff, Suzannah. Sight and Embodiment in the Middle Ages. The New Middle Ages. Houndmills and New York: Palgrave Macmillan, 2002.

http://dx.doi.org/10.1057/9780230508354

Bredow-Klaus, Isabel von. Heilsrahmen: Spirituelle Wallfahrt und Augentrug in der Flämischen Buchmalerei des Spätmittelalters und der frühen Neuzeit. Munich: Herbert Utz, 2009.

Browe, Peter. Die Eucharistischen Wunder des Mittelalters. Breslauer Studien Zur Historischen Theologie N. F. 4. Breslau: Verlag Müller \& Seiffert, 1938. 
Brumme, Carina. "Fromme Devotionalien und Volkstümliche Festrequisiten-zur Verwendung der spätmittelalterlichen Miniaturkronen." In Wallfahrer aus dem Osten: Mittelalterliche Pilgerzeichen zwischen Ostsee, Donau und Seine; Beiträge der Tagung "Perspektiven der europäischen Pilgerzeichenforschung," 21. bis 24. April 2010 in Prag. Edited by Hartmut Kühne, Lothar Lambacher, and Jan Hrdina. Europäische Wallfahrtsstudien 10 (2013): 461-74.

Buren, Anne Hagopian van. "Dreux Jehan and the Grandes Heures of Philip the Bold.” In Als Ich Can: Liber Amicorum in Memory of Professor Dr. Maurits Smeyers, edited by Bert Cardon, Jan van der Stock, Dominique Vanwijnsberghe, and Katharina Smeyers, 1377-414. Leuven: Peeters, 2002.

Burns, Thomas, and Patrick Cochran. The Communion Token. N.p.: Galata, 2011.

Bynum, Caroline Walker. "Bleeding Hosts and Their Contact Relics in Late Medieval Northern Germany." Medieval History Journal 7, no. 2 (2004): 227-41.

http://dx.doi.org/10.1177/097194580400700204

Bynum, Caroline Walker. Christian Materiality: An Essay on Religion in Late Medieval Europe. Cambridge, Mass.: Zone Books, distributed by the MIT Press, 2011.

Bynum, Caroline Walker. Wonderful Blood: Theology and Practice in Late Medieval Northern Germany and Beyond. Middle Ages Series. Philadelphia: University of Pennsylvania Press, 2007.

Courtenay, William J. “Token Coinage and the Administration of Poor Relief During the Late Middle Ages." Journal of Interdisciplinary History 3, no. 2 (1972): 275-95.

http://dx.doi.org/10.2307/202331

Cresswell, O. D. Cresswell's Comprehensive Directory of World Communion Tokens. Ottawa: Nadin-Davis, 1985.

Dick, Robert. Scottish Communion Tokens: Other Than Those of the Established Church. Edinburgh: A. Elliot, 1902.

Durling, Nancy Vine. "Birthmarks and Bookmarks: The Example of a Thirteenth-Century French Anthology.” Exemplaria 16, no. 1 (2004): 73-94.

http://dx.doi.org/10.1179/exm.2004.16.1.73

Forgeais, Arthur. Collection de Plombs Historiés Trouvés dans La Seine et Recueillis par Arthur Forgeais. 5 vols. Paris: Chez l'auteur et chez Aubry, 1862-66.

Foster-Campbell, Megan. "Pilgrimage through the Pages: Pilgrims' Badges in Late Medieval Devotional Manuscripts “ In Push Me, Pull You: Imaginative and Emotional Interaction in Late Medieval and Renaissance Art, edited by Sarah Blick and Laura Deborah Gelfand, 227-74. Studies in Medieval and Reformation Traditions. Leiden: Brill, 2011. 
Foster, Megan H. “Pilgrimage through the Pages: Pilgrim's Badges in Late Medieval Devotional Manuscripts.” PhD diss., University of Illinois at Urbana-Champaign, 2011.

Hiebsch, Sabine. "Tastbaar Geloof: Avondmaalsloodjes in Nederlandse Lutherse Gemeenten.” In Van Pakhuis tot Preekhuis: 425 Jaar Lutherse Gemeente in Amsterdam (1588-2013), ed. Sabine Hiebsch and Martin L. van Wijngaarden, 87-108. Zoetermeer: Boekencentrum, 2013.

Koldeweij, A. M. Geloof en Geluk: Sieraad en Devotie in Middeleeuws Vlaanderen. Arnhem: Terra, 2006.

Köster, Kurt. "Gemalte Kollektionen von Pilgerzeichen und Religiösen Medaillen in Flämischen Gebet- und Stundenbüchern des 15. und frühen 16. Jahrhunderts. Neue Funde in Handschriften der Gent-Brügger Schule." In Liber Amicorum Herman Liebaers, edited by F. L. J. Vanwijngaerden, Jean-Marie Duvosque, and Josette Mélard, 486-535. Brussels: Pour les Amis de la Bibliotèque royale Albert Ier par le Crédit Communal de Belgique, 1984.

Köster, Kurt. “Gutenbergs Aachener Heiltumsspiegel.” In Das Werck der Bücher: Von der Wirksamkeit des Buches in Vergangenheit und Gegenwart, edited by Fritz Hodeige, 284-301. Freiburg: Verlag Rombach, 1956.

Köster, Kurt. "Kollektionen Metallener Wallfahrts-Devotionalien und kleiner Andachtsbilder, eingenäht in spätmittelalterliche Gebetbuch-Handschriften." In Erlesenes aus der Welt des Buches, vol. 1 of Das Buch und Sein Haus: Gerhard Liebers Gewidmet zur Vollendung des 65. Lebensjahrs am 23. Mai 1979, edited by Bertram Haller and Rolf Fuhlrott, 77-130. Wiesbaden: Reichert, 1979.

Köster, Kurt. "Mittelalterliche Pilgerzeichen." In Wallfahrt kennt keine Grenzen: Themen zu einer Ausstellung des Bayerischen Nationalmuseums und des Adalbert Stifter Vereins, München, edited by Lenz Kriss-Rettenbeck and Gerda Möhler, 203-23. Munich: Schnell \& Steiner, 1984.

Köster, Kurt. Pilgerzeichen und Pilgermuscheln von Mittelalterlichen Santiagostrassen: SaintLéonard, Rocamadour, Saint-Gilles, Santiago de Compostela. Ausgrabungen in Schleswig. Neumünster: K. Wachholtz, 1983.

Köster, Kurt. "Religiöse Medaillen und Wallfahrts-Devotionalien in der Flämischen Buchmalerei des 15. und frühen 16. Jhs. zur Kenntnis Gemalter und Wirklicher Kollektionen in Spät-Mittelalterlichen Gebetbüchern." In Buch und Welt: Festschrift für Gustav Hofmann, zum 65. Geburtstag Dargebracht, edited by Hans Striedl and Joachim Wieder, 459-504. Wiesbaden: O. Harrassowitz, 1965.

Kumler, Aden. “The 'Genealogy of Jean le Blank': Accounting for the Materiality of the Medieval Eucharist." In The Matter of Art: Materials, Practices, Cultural Logics, c. 1250-1750, edited by Christy Anderson, Anne Dunlop, and Pamela H. Smith, 119-40. Manchester : Manchester University Press, 2015.

Kumler, Aden. "The Multiplication of the Species: Eucharistic Morphology in the Middle 
Ages.” Res 59/60 (2011): 179-91.

Levy, Ian Christopher, Gary Macy, and Kristen Van Ausdall, eds. A Companion to the Eucharist in the Middle Ages. Brill's Companions to the Christian Tradition. Leiden; Boston: Brill, 2011.

Macy, Gary. The Banquet's Wisdom: A Short History of the Theologies of the Lord's Supper. New York: Paulist Press, 1992.

Macy, Gary. The Theologies of the Eucharist in the Early Scholastic Period: A Study of the Salvific Function of the Sacrament According to the Theologians, c. 1080-c.1220. Oxford: Clarendon Press, 1984.

Mentzer, Raymond A. "The Reformed Churches of France and the Visual Arts." In Seeing Beyond the Word: Visual Arts and the Calvinist Tradition, edited by Paul Corby Finney, 199-230. Grand Rapids, Mich.: Eerdmans, 1999.

Rubin, Miri. Corpus Christi: The Eucharist in Late Medieval Culture. Cambridge and New York: Cambridge University Press, 1991.

Rudy, Kathryn M. "Dirty Books: Quantifying Patterns of Use in Medieval Manuscripts Using a Densitometer." Journal of Historians of Netherlandish Art 2, no. 1 (2010).

\section{http://dx.doi.org/10.5092/jhna.2010.2.1.1}

Rudy, Kathryn. "Kissing Images, Unfurling Rolls, Measuring Wounds, Sewing Badges and Carrying Talismans: Considering Some Harley Manuscripts through the Physical Rituals they Reveal." In Proceedings from the Harley Conference, British Library, 29-30 June 2009 (eBLJ, 2011, article 5): http://www.bl.uk/eblj/2011articles/article5.html

Rudy, Kathryn M. Postcards in Parchment: The Social Lives of Medieval Books. New Haven and London: Yale University Press, 2015.

Rudy, Kathryn. Review of Push Me, Pull You: Imaginative, Emotional, Physical, and Spatial Interaction in Late Medieval and Renaissance Art, edited by Sarah Blick and Laura D. Gelfand (Leiden: Brill Academic Publishers 2011): http://www.sehepunkte.de (June 2012).

Rudy, Kathryn M. "Sewing as Authority in the Middle Ages." Zeitschrift für Medien- und Kulturforschung (2015): 117-31.

Sciacca, Christine. "Raising the Curtain on the Use of Textiles in Manuscripts." In Weaving, Veiling, and Dressing: Textiles and Their Metaphors in the Late Middle Ages, edited by Kathryn M. Rudy and Barbara Baert, 161-90. Turnhout: Brepols, 2007.

http://dx.doi.org/10.1484/M.MCS-EB.3.1875

Thoss, Dagmar, and Otto Mazal. Das Buchaltärchen Herzog Philipps des Guten von Burgund: Codex 1800 der Österreichischen Nationalbibliothek in Wien = Le Livre-Autel de Philippe Le Bon, 
Duc de Bourgogne: Codex 1800 de la Bibliothèque Nationale Autrichienne de Vienne. Lucerne: Faksimile-Verlag, 1991.

Timmermann, Achim. "A View of the Eucharist on the Eve of the Protestant Reformation." In $A$ Companion to the Eucharist in the Reformation, edited by Lee Palmer Wandel, 365-98. Leiden: Brill, 2014.

Timmermann, Achim. Real Presence: Sacrament Houses and the Body of Christ, c. 1270-1600. Architectura Medii Aevi. Turnhout: Brepols, 2009.

Travaini, Lucia. “Coins as Bread. Bread as Coins," The Numismatic Chronicle 173 (2013), 187-200.

Whitelaw, H. A. Communion Tokens: With Illustrated and Descriptive Catalogue of Those of Dumfriesshire. Dumfries: Council of the Dumfries and Galloway Natural History and Antiquarian Society, Dumfries and Maxwelltown Ewart Public Library, 1911.

Wieck, Roger S. Time Sanctified: The Book of Hours in Medieval Art and Life. New York: G. Braziller, in association with the Walters Art Gallery, Baltimore, 1988.

Winter, Patrick M. de. "The Grandes Heures of Philip the Bold, Duke of Burgundy: The Copyist Jean l'Avenant and His Patrons at the French Court." Speculum 57, no. 4 (1982): 786-842. http://dx.doi.org/10.2307/2848764

Winter, Patrick M. de. La Bibliothèque de Philippe Le Hardi, Duc de Bourgogne (1364-1404): Étude sur les Manuscrits é Peintures d'une Collection Princière à L’époque du "Style Gothique International." Documents, Études et Rèpertoires / Institut de Recherche et d'histoire des Textes. Paris: Centre national de le recherche scientifique, 1985.

Wormald, Francis, and Phyllis M. Giles. "Description of Fitzwilliam Museum Ms. 3-1954." Transactions of the Cambridge Bibliographical Society 4, no. 1 (1964): 1-28.

Zika, Charles. "Hosts, Processions and Pilgrimages: Controlling the Sacred in Fifteenth-Century Germany." Past and Present 118 (1988): 25-64.

http://dx.doi.org/10.1093/past/118.1.25

\section{Recommended Citation:}

Kathryn M. Rudy, "Sewing the Body of Christ: Eucharist Wafer Souvenirs Stitched into Fifteenth-Century Manuscripts, primarily in the Netherlands," JHNA 8:1 (Winter 2016), D0l: 10.5092/jhna.2016.8.1.1 